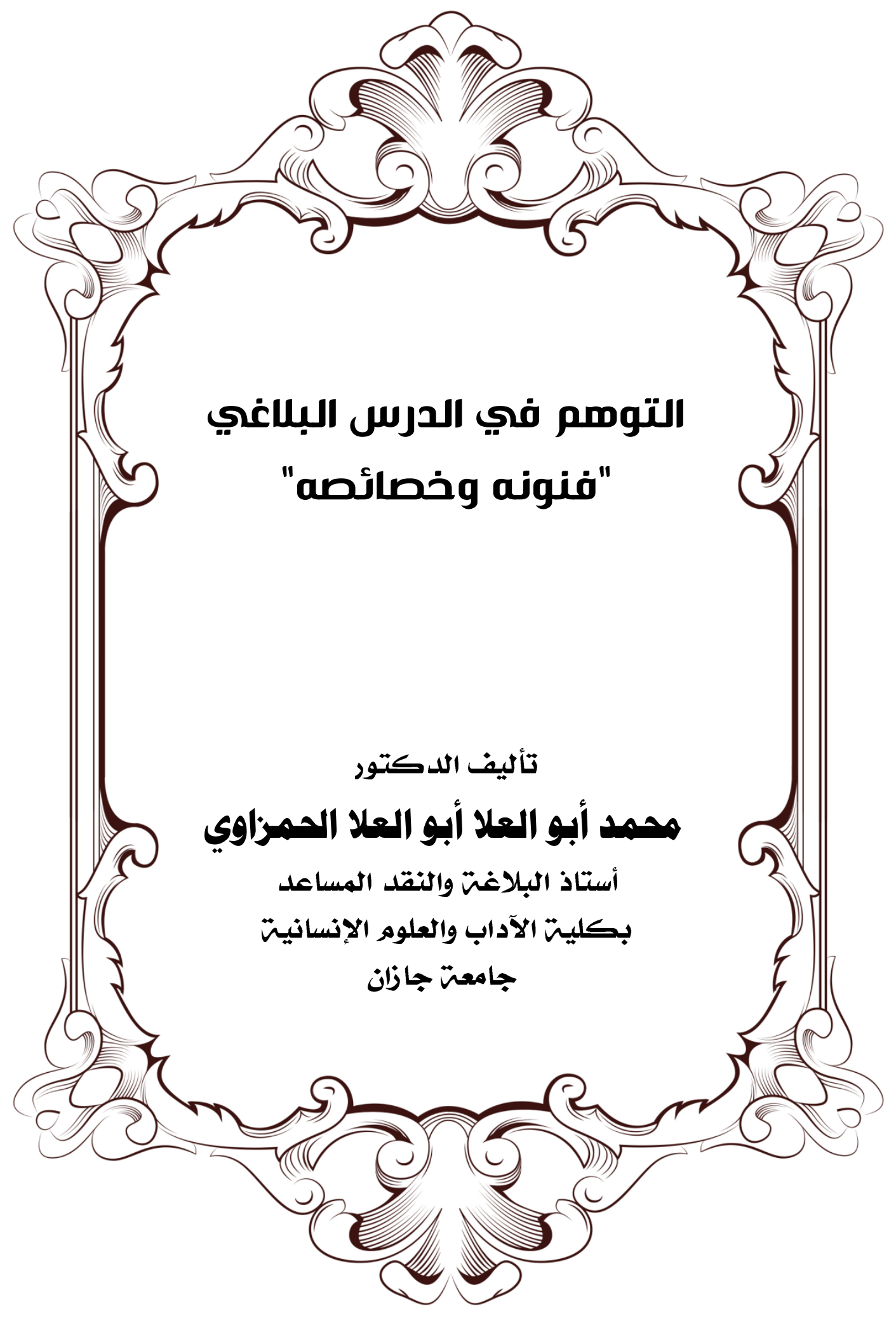





\section{ملخه البهـث}

\section{"التوهم في الدرس البلاغي "فنهونه وخصائصه"}

يتجه هذا البحث لدراسة ظاهرة التوهم في الدرس البلاغي العربي

ليكثف عن معنى التوهم عند البلاغيين، ودوره في نشكيل المعنى

وعلاقته بالخيـال والتصـور ، كمـا يكثـف عن الفنـون البلاغيـة التي

تـدخل تحــت هـذه الظـاهرة، ويبـين دور التـوهم في الكثـف عـن

وجدانيات النفس، وأثره في التعبير عن المعاني، ومـا ينطوي عليه

من خداع وإيهام للنفس أو المخاطب، وما وراء ذلك من أسرار بيانية.

ويحرض البحث أيضـاً على بيان التقاء ظلاهرة التوهم في الدرس

البلاغي مـ أحدث ما وصلت إلبه النظربات البلاغية والنقدية حول

التوصيل والتلقي.

\section{كلمات ممتتاحيت}

التوهم، التصور، الخيال، الإيهام، التخبيل 
حوليتة كليت اللغت العربيت بإيتاى البارود (العدد الثاني والثلاثون ـ المجلد الثالث)

\section{Abstract \\ 'suspicion in rhetorical and characteristics of Arts' lesson '}

Heading this research to study the phenomenon of suspicion in Arab rhetorical lesson reveals the meaning of suspicion when the rhetorical 'And its role in the formation and its relationship to fantasy and imagination, as it reveals the rhetorical arts that fall under this phenomenon' It shows the role of illusion in detecting wegdaniat and its impact on the expression of meanings, of deception and illusion of self or thnx, beyond graphic secrets.

And also search a statement incites the confluence phenomenon of illusion in rhetorical lesson with the latest rhetorical theories and cash on delivery and reception.

\section{Keywords}

Illusion, perception, fantasy, illusion, imagining 
حوليت كليت اللغت العربيت بإيتاى البارود (العدد الثاني والثلاثون ـ المجلد الثالث)

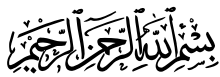

in

الحمد الله حمداً يوافي نعمه ويكافئ مزيده، وأصلي وأسلم على النبي المجتبى، أفصح خلق الله بياناً، وعلى آله وصحبه أجمعين.

\section{وبـ}

فان البيان العربي بيان حافل بفنون من التعبير تمكن الثـاعر والكاتب من إنتاج نصده، والتعبير عن انزياحاته النفسية، وما بدور في وجدانيات نفسه، وقيمة البيان تكمن في قدرته على التأثير والتوصيل مع مراعاة خصوصيات المعنى ومـا يتطلبـه لأجـل الإفـادة مـن جمالبـات اللغـة وقدرتها على إيصـال المعنى إلى المتلقي. ومن الظواهر البلاغية التي تميز بها البيان العربي، ولها حضور كبير في فنونه المنتوعة: ظاهرة التوهم؛ حيث نجد لها أثرا كبيرا في تشكيل المعنى، والتعبير عن الغرض مع اختاف السياقات في عدد من ألوان البيان. ولقد لفتي حضور هذه الظاهرة في بيانتا العربي، وكان من أسباب اختيار البحث: ما لهذه الظاهرة من مدخل وأثر في تشكيل المعنى، والتعبير عن خيـالات الكتاب والثـعراء، ومـا تشـتمل عليهـا مـن أغـراض بـاغيـة، مـع التقائها مـع أحدث مـا وصـلت إلبـه نظربـات النص والتلقي، ودراسـات الخيـال وأثره في الفن الأدبـي. كذلك قلـة الدراسـات التي تصدت لبيـان " التوهم" في الـدرس البلاغـي، فجـاء البحـث ليقوم بـاجتلاء هـذه الظـاهرة، وبكثـف عـن أبعادها، وفنونها، وخصائصها في بيانتا العربي، ويبين ما وراءها من أسرار ترتبط بالمعنى، ويوضح مدى إدراك علماء البلاغة لهذه الظاهرة، وبكثف عن وجوه الاتفاق بينها وبين المذاهب النقدية الحديثة التي عنيت بدراسـة التوهم والخيال في الفن الأدبي. والبحث يتكون من مقدمة، وتمهيد، وثلاتثة مباحث، وخاتمة، وفهارس. أما المقدمـة فقيهـا أسـباب اختيـار البحـث، والتمهيـد يثـتمل على مفهوم التـوهم 
حوليت كليت اللغت العربيت بإيتاى البارود (العدد الثاني والثلاثون ـ المجلد الثالث)

وتطوره، والفرق بينه وبين الخيال والتصور ، والفرق بين التوهم عند النحوبين والبلاغيين.

والمبحث الأول: التوهم في أساليب وفنون المعاني.

والمبحث الثاخي: التوهم في صور البيان.

والمبـحث الثالث: التوهم في أساليب وألوان البديع.

والخاتمة وفيها نتائج البحث، وفهارس المصادر والمواضيع.

و الله أسأل أن يوفقنا إلى الصواب، ويهدينا إلى طريق الرشاد. 


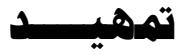

\section{مغهوهر التوهم وتطوره:}

توهم الثـيء: تخيله وتمثله كان في الوجود أو لـ يكن، قال الجوهري:

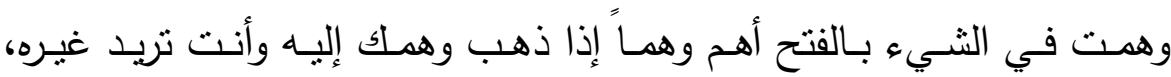

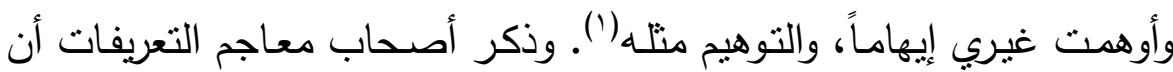
التوهم: إدراك المعنى الجزئي المتعلق بالمحسوس(؟)، وذكر المناوي أنه: سبق وهي

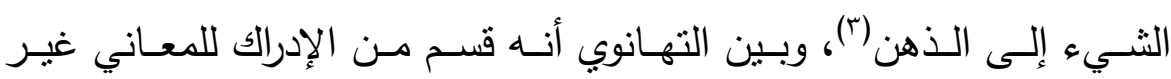
المحسوسة من الكيفيات والإضـافات، ويشترط فيه كون المدرك جزئياً كما في الإحساس والتخيل (؛). فالتوهم يكون في الأمور المحسوسة وغير المحسوسة التي تتصورها النفس. ونرى لبعضهم كلاماً دقيقاً على الفرق بين الأمور الخيالية والأمور الوهمية، لتهونة يقول العلوي: "والتفرقة بين الأمور الخيالية والأمور الموهومة هو أن الخيال

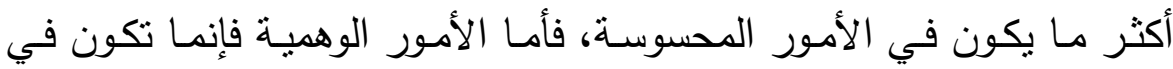

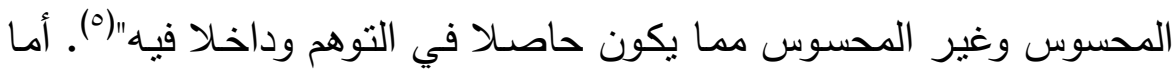

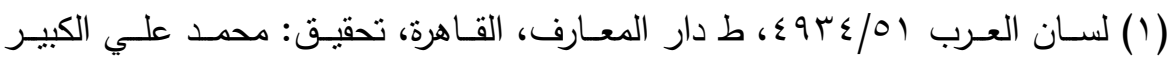
وآخرين.

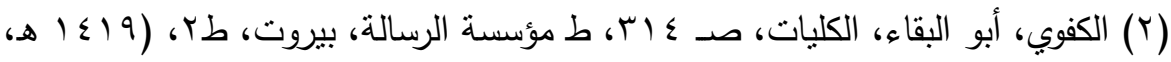
1991 ام، تحقيق: عدنان درويش، ومحمد المصري.

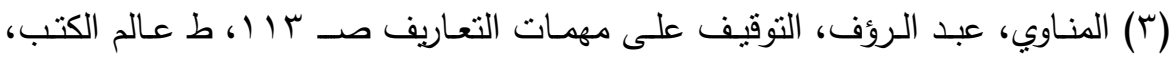

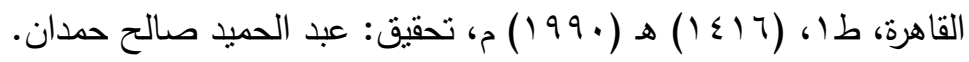

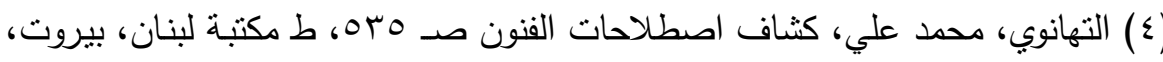

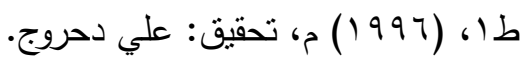

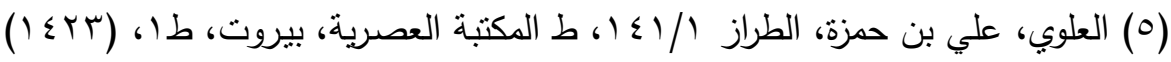
هـ (Y... (Y) م، تحقيق: عبد الحميد هنداوي. 
حوليت كليتة اللغت العربيت بإيتاى البارود (العدد الثاني والثلاثون ـ المجلد الثالث)

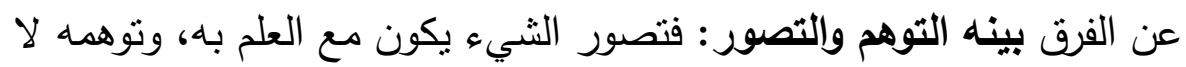

يكون مع العلم به؛ لأن التوهم من قبيل التجويز ، والتجوبز ينافي العلم"('). أول من أثثار إلى التـوهم: يعد أحمد بن فارس (ت بهوب) هـ أول من أثـار

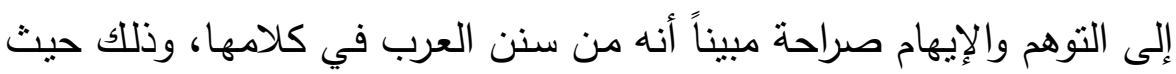
يقول: "ومن سنن العرب التوهم والإيهام، وهو أن يَتوهم أحدهم شيئًا ثم يجعل

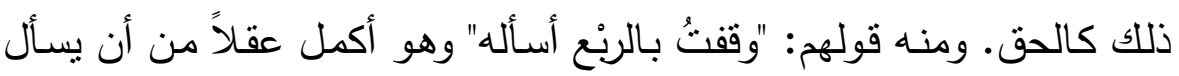

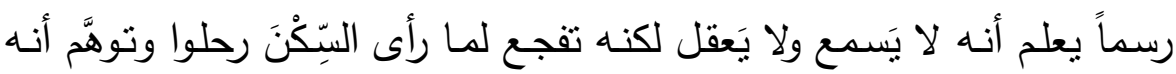

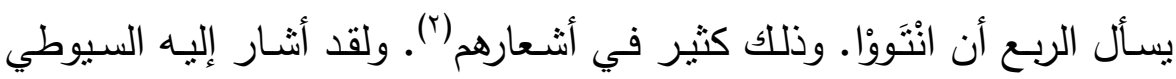

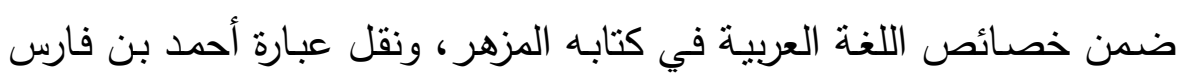

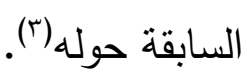

" كما ظهر لفظ التوهم في مصنفات النحو الأولى بدءاً بكتاب سيبويه

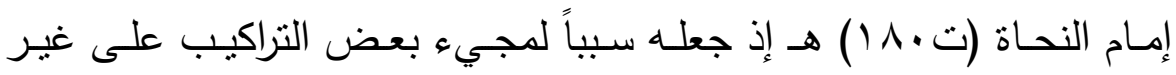

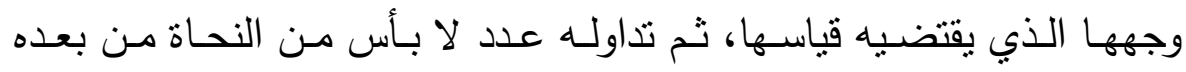
كالكسائي والفراء، والفارسي، وابن جني، والمالقي، والهروي، وابن مالك، وأبي

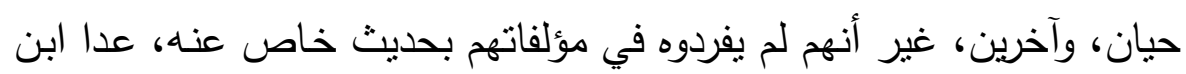

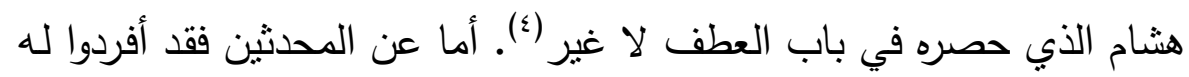
بحوثاً خاصة تدرجت ما بين الوريقات إلى البحوث المنشورة، والرسائل العلمية،

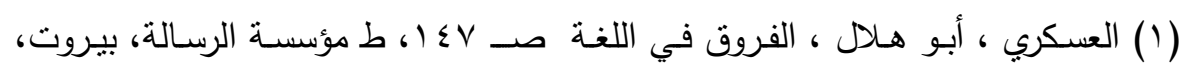

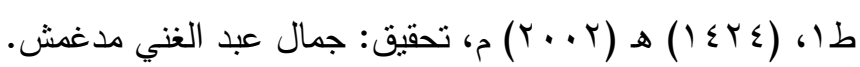

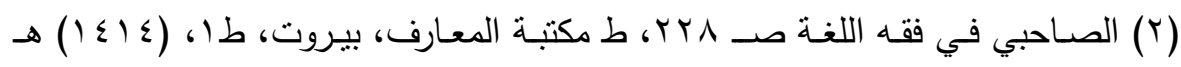

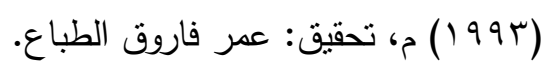

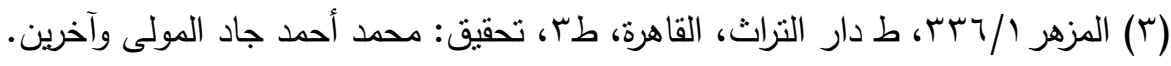

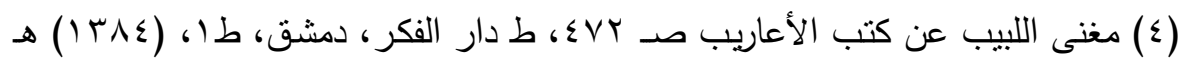

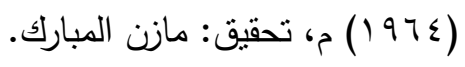


حوليتّكليت اللغت العربيت بايتتاى البارود (العدد الثاني والثلاثون ـ المجلد الثالث)

والكتب التي تتتاول ظاهرة التوهم من جوانب متعددة('). وكل هذه الدراسـات والبحوث اتجهت لاراسـة التوهم عند اللغويين والتحوبين، وتتوعت مـا بين قبوله ورفضه، أو التحفظ على هذا المصطلح، ودراسة الفرق بينه وبين الخطأ، وغير ذللك، وهو مما لا يتصل بمقاصد البحث البلاغي هنا. التـوهـر عنـد البيلاغيـيـن: أمـا عن البلاغيـين فنجد قلة الدراسـات التي اتجهـت إلىى دراسـة التـوهم عندهم، وهنـاك فـرق كبيـر مـا بـين التـوهم عندـ البلاغيين والنحوبين. فالتوهم عند البلاغيين يدخل ضدن الأغراض البلاغيـة التي ترتبط بالخيال والوجدان والتصسور، فهو حالة من حالات النفس ترتبط بالوجدان ومـا يتصـوره من أمسور تعبر عن نفسية صساحبها، وتدخل ضـمن عناصر الفن الأدبي بما فيها من خداع وإيهام للنفس أو للمخاطب. فالتوهم من الناحية البلاغية هو حمل للأمور على خلاف مقتضى الظاهر منها أو عكس لتصورها، أو إخفاء لحقيقتها لغرض بلاغي يرتبط بالمعنى والسياق، إن التوهم هنا ليس من قبيل الخطأ في المعنى، أو من قبيل الغلط في التصور، أو من قبيل التفسير التخيلي للتوفيق في المعنى أو ليكون محمولاً على صسورة من صور القباس كما هو الحال عند النحوبين. بل إن الأمر هنا من قبيل الإيهام فيه لأجل التوصل إلى غرض بلاغي يرتبط بالسياق والمقام؛ ولذلك تنتـعب مواضعه وتتراحب آفاقه في الدرس البلاغي على حسب ما يقتضيه المقام كما سيتضـح إن شـاء الله. فهو وسيلة للتعبير عن الانحرافات النفسية وانزياحاتها عن الثـاعر أو الكاتب، أو وسيلة للتأثير في المتلقي، وعكس لتصوره، وهو بهذا يلتقي مـع الرؤيسة النقديـة الحديثة للبلاغـة وديناميتهـا، ودورهـا كوسـيلة للتوصيل، والتعبير عن الخيال والوجدان.

(1) الغامدي، محمد سعيد، التوهم في آتار الدارسين عرض ونقد صـ r ب، بحث منشور بمركز البحوث والنشر العلمي، جامعة الملك عبد العزيز. 
حوليت كليت اللغت العربيت بإيتاى البارود (العدد الثاني والثلاثون ـ المجلد الثالث)

وقد أشـار البلاغيون إلى التوهم، ووجوهـه وهم بصدد الحديث عن بعض

الفنون والأنـواع البلاغيـة، فتعرضـوا لهذا المصسطلح عند ذكر التوريـة؛ حيـث

ذُكرت باسم "الإيهام والتخييل" لما فيها من خفاء المراد وإيهام خلافه(').

وتحدث ابن أبي الإصبع عن التوهيم "بأن يأتي المتكلم في كلامه بكلمة

يوهم مـا بعدها من الكحلام أن المتكلم أراد تصـحيفها، ومراده على خـلاف مـا

يتوهم السامع منها"(r)، وتحدثوا عن دفع توهم التجوز في أغراض توكبد المسند إلبه، والوصل لدفع الإيهام وتحدثوا عن التشبيه الوهمي... إلى غير ذلك من فنون التوهم التي ترتبط بالمقاصـ والأغراض البلاغيـة والتي سيكثف عنها البحث. فالمقصود هنا من مصطلح "التوهم" الذي يرمي إلبه البحث مـا هو أوسـع مـن التوريـة أو التصـحيف أو نحوهمـا، فـالتوهم هو صـورة واسـعة مـن صور المجاز والعدول عن الظاهر من الكلام، أو التخييل بايهام خلاف المراد من المعنى، أو أن يذهب وهمك إلى شيء وأنت تريد غيره، أو أن توهم غيرك بثـيء مـع إرادة غيـره أيضـاً لغـرض مـن الأغـراض البلاغيـة التـي تختلـف بـاختلاف السـباق والمقـام. ولقـد لفتـي مـا رأيــت مـن روعـة التخييـل، وكثرة الأغراض البلاغية وتعددها خلف هذا المصطلح الواسع في الدرس البلاغي، ووجدت صوراً كثيرة، وآفاقاً منراحبة لهذا التوهم في الصور والتراكيب المختلفة على امتداد مباحث البيان العربي وفنونـه، ورأيت حضوراً كثيفاً لـذه الظاهرة

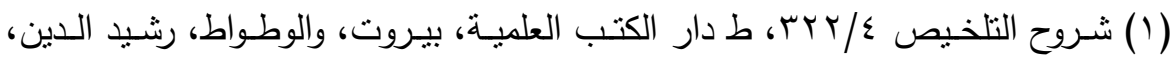

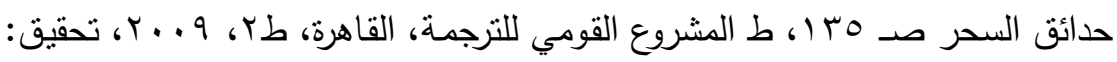

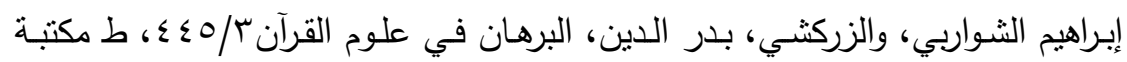

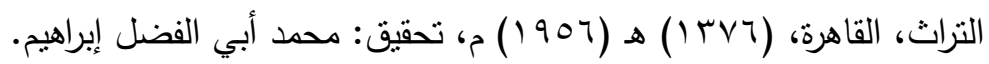

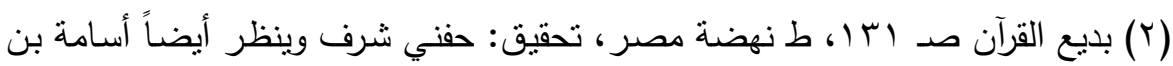

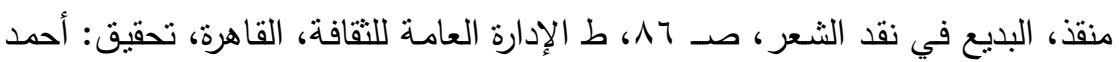

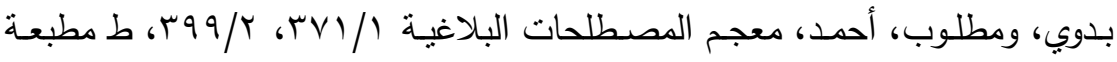

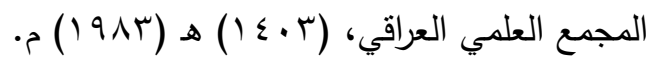


حوليتّ كليت اللغت العربيتّ بإيتاى البارود (العدد الثاني والثلاثون ـ المجلد الثالث)

البيانيـة، ووجدت وراءهـا أسـرارا تتــوع تبعًَا للسـياقات والمقامـات. فـأردت أن أكثَف عن التفات البلاغينين لهذه الصـنعة البيانبـة، ومـا وراءهـا مـن أسـرار بلاغية، والفنون البيانية التي يدخلها التوهم عندهم، وكيف يمكن الإفادة من هذه الظاهرة في تحليل ودراسة أساليب البيان شعراً ونثراً، وكيف وظف الثعراء والأدباء هذه الظاهرة في أثـعارهم تخيبلاً وتصسويراً، وبيان مـا تتميز بـه من خصائص وسمات.

$\hat{1}\} \hat{-10}$ 


\section{المبحث الأول}

\section{التوهم في أساليب ومسائل المعاني}

أثنار البلاغيون إلى التوهم وهم بصدد دراسـة النظم في الجمل والتراكيب، وما يعرض لها من خصائص بلاغية تختلف باختلاف السياق والمقام من ذكر

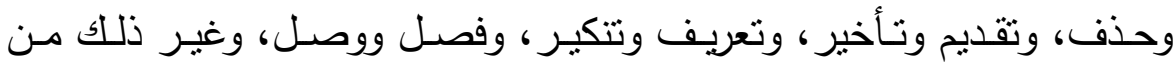

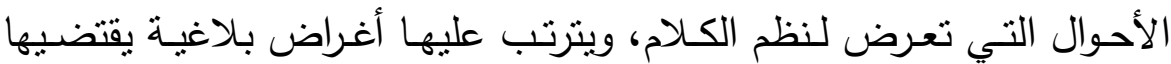
السياق، ونلمح الإشارة إلى غرض التوهم صراحة في مواضع كثيرة مما ذكروه،

\section{أغراض حذف المسند إليه:}

حيث ذكروا من أغراض الحذف: التخييل أن في تركه تعويلاً على شـهادة العقل، وفي ذكره تعويلاً على شهـادة اللفظ من حيث الظـاهر، وكـم ببين

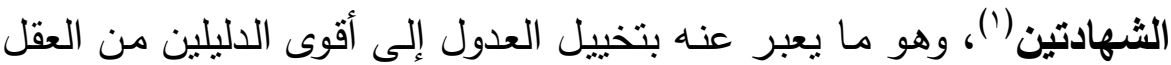
واللفظ" كقولنا: قائم في جواب: كيف زيد؟ فحذفنا المسند إليه، والتقدير : زيد قائم، وكان حذف المسند إليه في تخييل العدول إلى أقوى الدليلين؛ لأنك لو قلت: زيد قائم، أو هو قائم مثناً: لكان الكلام دالاً على المسند إليه بلفظه، ولو إله قلت قـائم فحذفت المسـند إليـه لعرفـه المتلقي بالعقل الذي يفهم أن السؤال كالمعاد في الجواب. فالدليلان هما: دليل العقل، ودليل اللفظ، وأقواهها دليل

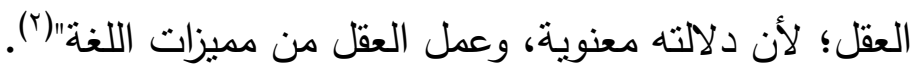
وإما لإيهام أن في تركه تطهيراً لـه عن لساتك، أو تطهيراً للساتك عنه. إن من السمات العامة وراء ظاهرة الحذف بعث الفكر وتتشيط الخيال، وإثارة الانتباه ليقع السـامع على مراد الكـلام، ويستتبط معناه من القرائن والأحوال،

(1) القزويني، الخطيب، الإيضاح// (1) 1999، ط مكتبة الآداب، القاهرة، (199) م.

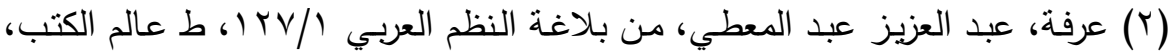

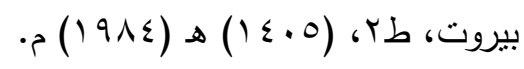


حوليتة كليت اللغت العربيت بإيتاى البارود (العدد الثاني والثلاثون ـ المجلد الثالث)

وخير الكلام ما يدفعك إلى التفكير ('). ونلمح إثـارة البلاغيين إلى دفع التوهم أو السهو وهو بصدد الحديث عن أغراض توكيد المسند إلبه، فلقد ذكروا من أغراض التأكيد: دفع توهم التجوز أو السهو أو عدم الشمول(r) بأن يكون في الكلام أو المقام ما يوهم ذلك فيؤتى بالتوكيد لدفعه(r). ومثال دفع تـوهم التجوز: قولك "قطع الأمبر نفسـه السـارق" فلولم تقل "نفسه" لتوهم أن القاطع غيره بأمره على ما جرت بـه العادة. وأمـا دفع توهم السهو فنحو قولك: نجحت أنا ، وجاعني محمد محمد، فهذا التأكيد يدفع توهم السامع أن المنكلم سها في إثبات الحكم لغير ما هو له، وأمـا دفع توهم عدم الشمول فكقولل: عرفني الرجلان كلاهما، فلو قلت: عرفني الرجلان بلا تأكيد لتوهم أن أحد الرجلين هو الذي عرفلك، ولكنك لم تعتد بما لم يعرفلك فأطلقت الكل وأردت الجزء على سبيل المجاز ، فدفعاً لهذا التوهم جاء التوكيد لإفادة الثـمول والعموم"(๕). ولهذا النوع من التأكيد نظائر في القرآن الكريم، ومنها

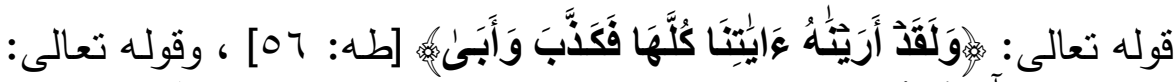

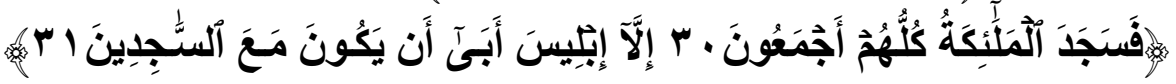

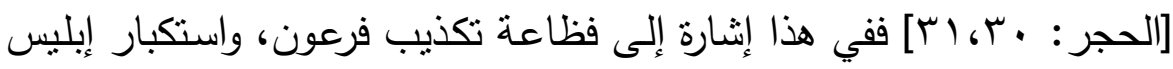
اللعين"(0). وهي إثشارات مههة تدل على إدراك المتقدمين لخصائص الأساليب،

(1) أبو موسى، محمد، خصائص التراكيب صـ • 7 (، ط مكتبة وهبة، طع، (7 اع () هـ (1) (1)

$$
\text { الإيضاح (1997) ) م. 190/1) }
$$

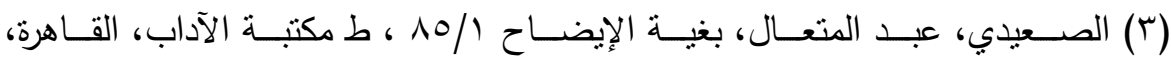

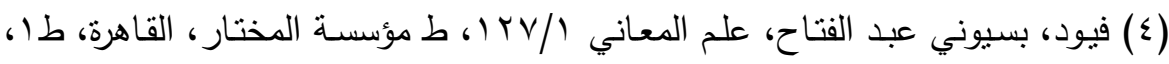

$$
\begin{aligned}
& \text {. (199人) (1 (19) } \\
& \text { (0) بغية الإيضاح /10/1. }
\end{aligned}
$$


حوليت كليت اللغت العربيت بإيتاى البارود (العدد الثاني والثلاثون ـ المجلد الثالث)

وما بدخلها من التوهم في المعنى في ذهن السامع، ونلمح فيها مـا أثـار إليه المحدثون حول نظرية التوصيل، ومراعاة أطراف الحوار عند الخطاب.

\section{تعريف الخبر:}

نجد لعبد القاهر الجرجاني كلاماً حول ما سماه بـ " الموهوم" وهو بصدد

الحديث عن تعريف الخبر بالألف واللـلام، وتعريفهه بـ " الذي" ، وقد ذكر أن هذا الجنس من المعهود في "الوهم والتخيل"، "ففي قولك "هو البطل المحامي"

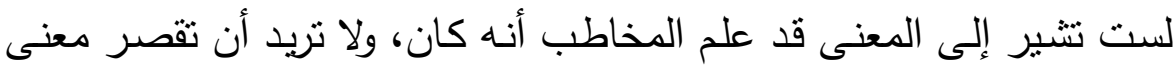
عليه على معنى أنه لم يحصل لغيره على الكمال.... ولكنك تريد أن تقول لصـاحبك: هل سمعت بالبطل المحـامي؟ وهل حصلت معنى هذه الصـفة؟ وكيف ينبغي أن يكون الرجل حتى يستحق أن يقال ذلك لله وفيه؟ فإن كنت هـ قتلته علماً، وتصورته حق تصوره، فعليك صاحبك واشدد به يدك، فهو ضالتكا وعنده بغيتلك... فهذا كله على معنى الوهم والتقدير ، وأن يصور في خاطره

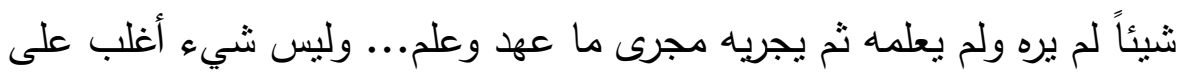

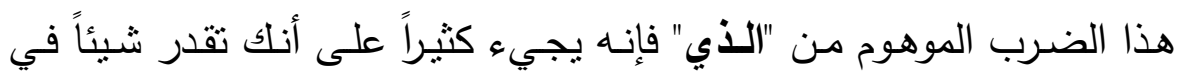
وهمك ثم تعبر عنه بـ "الأي"، ومثال ذللك قوله:

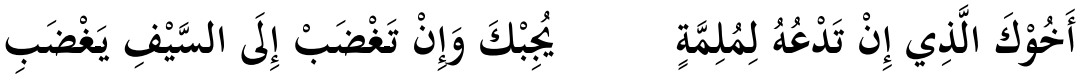

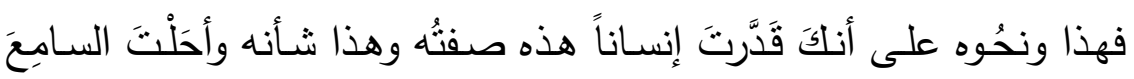

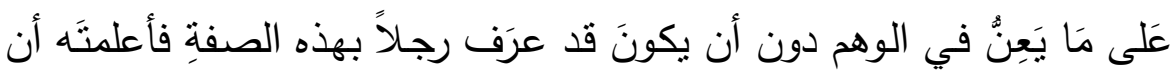

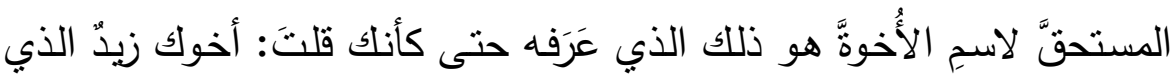

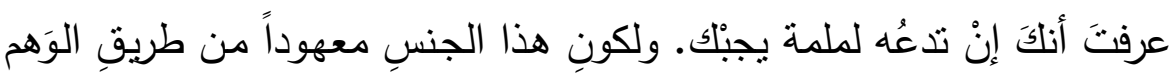

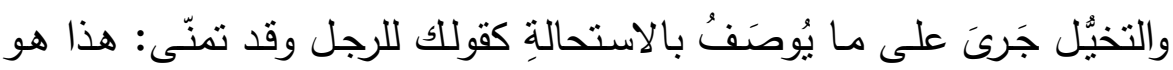
الذي لا يكونُ وهذا ما لا بَذْخُلُ في الوجود" (').

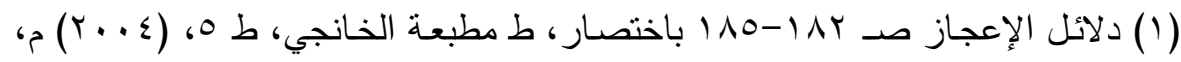
تحقيق: محمود شاكر . 
حوليتة كليت اللغت العربيت باييتاى البارود (العدد الثاني والثلاثون ـ المجلد الثالث)

ونلمـح هنـا أن عبد القاهر الجرجاني يقيم رؤيته حول التوهم على مـا

يفترضه المنكلم في خياله، ويحاول أن بنقله على ما استقر في خيال السامع،

وهو افتراض لما يدور في الخيال والوهم حول معنى الصفة ومقدار تحققها في النفس، وكيف ينتقل الخيال بين ما هو موهوم في النفس، وما هو متحقق في الموصوف من حيث الواقع، أي كيف يرى المخاطب ما بدور في الوهم حول الصفة متحقق في الموصوف في الواقع. فهذا النوع مبني على الوهم والتقدير، أي تقدير صورة مثالية، والتي يكون لها نظيراً في الواقع في الاسم المعرف(')، وإن شئ قلت: إسقاط ما هو متصور في الوهم والخيال حول الصفة وتمامها في القوة والكمال على عالم الواقع لهذه الصفة وتحققها في الموصوف؛ ولذك كان مـن المسـالك الدقيقة مـن التوهم، وإثـارة عبد القاهر إلبهه مـن الإشـارات الدقيقة التي غفل عنها المتأخرون، ولم بحوموا حولها. تقييل المعل بالشـرط في " إن، واذا": أشـاروا إلى حصول التوهم في "ي أغراض تقييد الفعـل بالثـرط في " إن، وإذا" فبعـد أن بينـوا أنهمـا للثـرط في إني الاسـتقبال، وأنهمــا يفترقـان فـي أن الأصـل فـي "إن" ألا يكـون الثـرط فيهـا مقطوعاً بوقوعه، والأصل في "إذا" أن يكون الثرط فيها مقطوعاً بوقوعه، وأنه الهـ

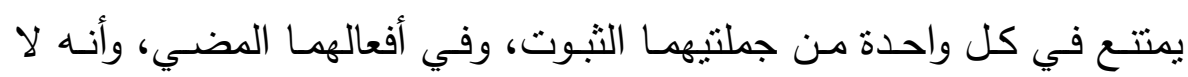
يخالف في ذلك إلا لنكتة: "منل إبراز غير الحاصل في صورة الحاصل إما لقوة الأسباب المتآخذة في وقوعه كقولك: "إن اشترينا كذا" حال انعقاد الأسباب في ذللك. وإما لأن ما هو للوقوع كالواقع: "إن مت كان كذا وكذا". وإمـا للتفـاؤل، وإمـا لإظهـار الرغبـة في وقوعـه نحو "إن ظفرت بحسن العاقبة فهو المراد" فإن الطالب إذا تبالغت رغبته في حصول أمر يكثر تصوره

(1) شادي، محمد إبراهيم، شرح دلائل الإعجاز صـ ب7 ب، ط دار اليقين للنشر والتوزيع،

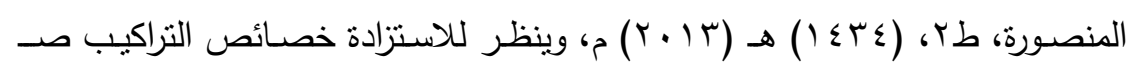


حوليتّ كليت اللغت العربيت بإيتاى البارود (العدد الثاني والثلاثون ـ المجلد الثالث)

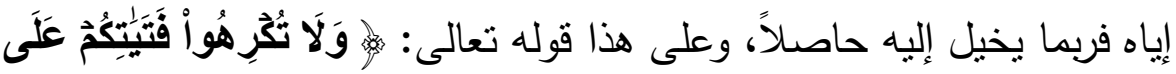

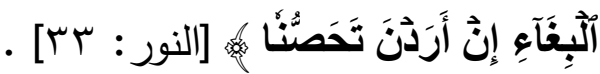

وقد يقوى حكم هذا التخييل عند الطالب حتى إذا وجد حكم الحس بخـلاف حكمه غلطه تارة، واستخرج لله محملاً أخرى، وعليه قول أبي العلاء المعري: ما سرت إلا وطيف منك يصحبني ... سري أمامي وتأويباً على أثرى يقول: لكثرة مـا ناجيت نفسي بـك انتفثـت في خيالي فأعدك بين يدي مغلطًا للبصر بعلة الظلام إذا لم يدركلك ليلًا أمامي، وأعدك خلفي إذا لم يتيسر لي تغليطه حين لا بدركك بين بدي نهارًا"(1). وهنا إثـارات دقيقة إلى دور التوهم فيما يكثر دورانه في الخاطر والخيال، وكيف يكون الكـلام معبرًا عما بدور في خوالج النفس وخفاياهـا، معبراً عن صورة الذهن، مبرزًا لمكنونـات النفس، ودسائسها، كيف يكون التقديم وسيلة للتعبير عما يدور في النفس، وكذلك كيف يكون تحول الزمن في دلالات "إن، وإذا" معبرًا عن حالات من حالات الوهم في النفس. تقدليم بعض المعمولات على بعض: أثـاروا إلى ذلك في تقديم بعض معدولات الفعل على بعض، فقد يكون الغرض من التقديم العناية بالمقدم، والاعتنـاء بشأنه لكونهـ في نفسـه نصب عينيك، كما تجدك قد منيت بهجر حبيبك وقيل لك: ما تتمنى؟ تقول: وجه

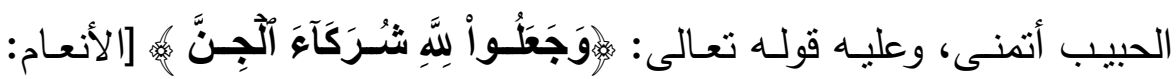
· . . 1 أي على القول بأن لله شركاء مفعولا "جعلوا"، أو لعارض يورثنه ذلك كما

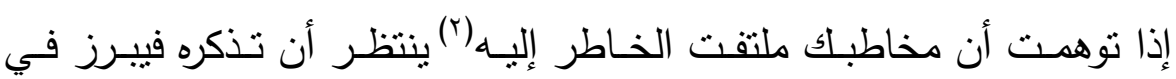
معرض أمر يتجدد في شأنه التقاضي ساعة فساعة فمتى تجد لله مجالا للذكر

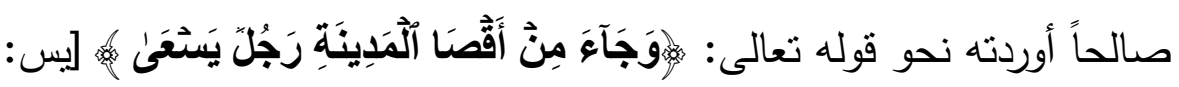

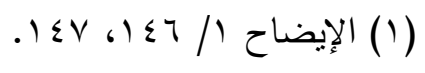
(Y) أي إلى معنى ينتظر من مساقلك الحديث إلمامك به. 
حوليت كليت اللغت العربيتّ بإيتاى البارود (العدد الثاني والثلاثون ـ المجلد الثالث)

• ب] قدم فيه المجرور لاشتماله مـا قبله على سوء معاملـة أهل القربـة الرسل من إصرارهم على تكذيبهم فكان مظنة أن يلعن السامع على مجرى العادة تلك القربـة وبيقى مجيلاً في فكره أكانت كلهـا كذلك أم كان فيهـا قُطر -دانٍ أم قـاص - منبــت خيـر منتظـراً لإلمــام الحـديث بـهـ بخــلاف مـا فـي سـورة

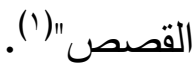

\section{الأفصل والوصل:}

تعـرض البلاغيـون للحديث عـن التوهم وهـم بصـدد بحـث " أحـوال

الفصل والوصل"، وما بين مواضعهما من فروق، فذكروا من مواضـع الفصل "ثبه كمال الانقطاع" بأن نكون الجملة الثانية بمنزلة المنقطعة عن الأولى،

لكون عطفها عليها موهماً لعطفها على غيرها، ويسمى الفصل لذلك قطعاً"(r). فهنالك جملـة مسبوقة بجملتين يصسح وصـلها بـالأولى منهمـا لوجـود المناسبة التي تسوغ الوصل، ولا يصح عطفها على الثانية، فيترك العطف دفعاً لتوهم العطف على الثانية، وتصبح الجملة الثالثة بمنزلة المنقطعة عن الأولى بهذا الحائل(r)، وهنا النظر للتوهم من زاوبية أخرى تتصل بطبيعة الجمل، وما يحمله العطف وتركه من صور ترتبط بالوهم والخيال. ولقد ذكروا من امثلته قول الثاعر : n

(1) هو قوله تعالى في قصسة موسىى:

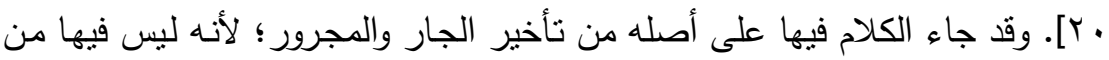
ذلك ما يقضي تقديمهما في الآية الأولى لتبكيت أولئك القوم بكون البعيد عمّا شاهدوا

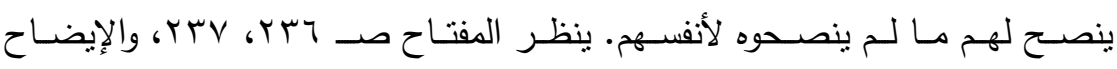

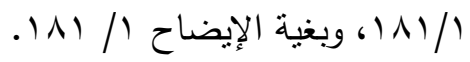

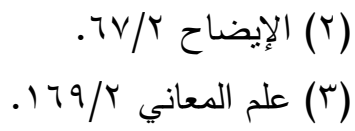


حوليت كليت اللغت العربيتّ بإيتاى البارود (العدد الثاني والثلاثون ـ المجلد الثالث)

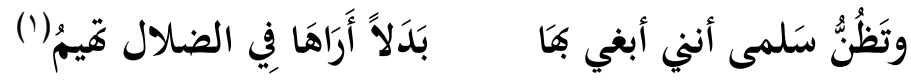

"فقد فصل جملة " أراها في الضلال..." عن الجملة الأولى " تظن سلمى..." لأن عطفها عليها يوهم أنها معطوفة على جملة " ... أبغي بها بدلاً" فتكون بهذا من مظنونات سلمى، وهي من كلام الثاعر لا من مظنوناتها، فذفعاً لهذا

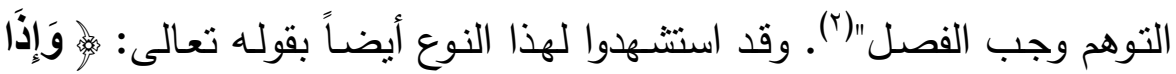

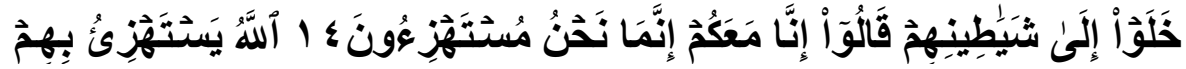

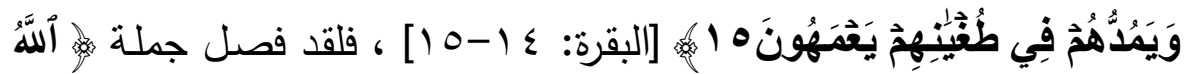

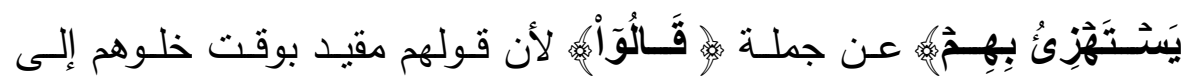

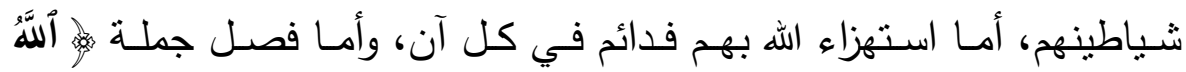

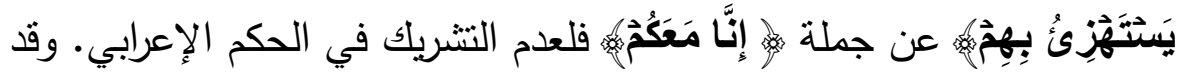
جعل السكاكي القطع في البيت السـابق من القطع للاحتباط وهو مـا لم يكن لمـانع من العطف، وجعل القطع في الآيـة من القطع للوجوب، وهو مـا كان لمـانع (r)، وبمكن رد سـبب الفصـل في الثـاهدين السـابقين إلـى شـبه كمال الاتصال كما نبه كثير من البلاغيين (๕).

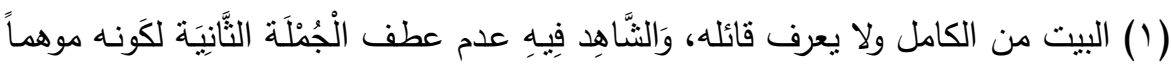

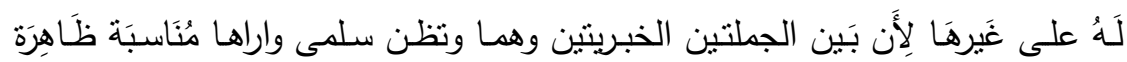

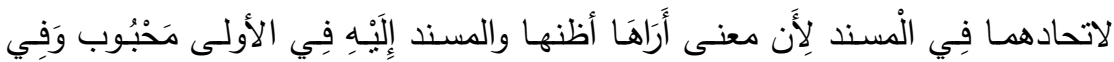

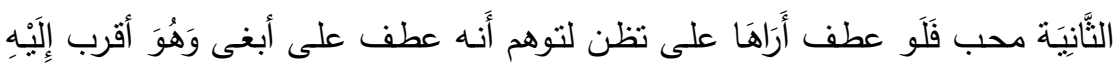

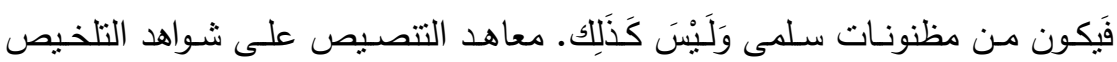

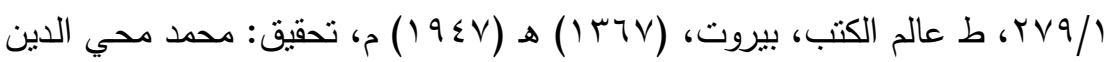

$$
\text { عبد الحميد. }
$$

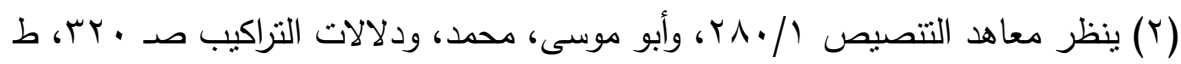

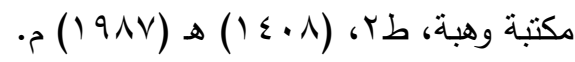

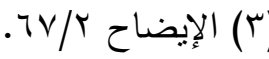

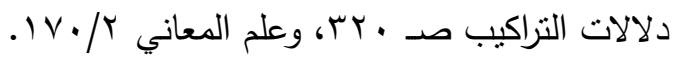


حوليت كليت اللغت العربيتّ بإيتاى البارود (العدد الثاني والثلاثون ـ المجلد الثالث)

الوصل لدفع الإبهام "كمال الانقطاع مع الإبـهام": وكما ذكروا الفصل لشبه

كـال الانقطاع وراءه مـن الإيهام ذكروا أيضـا من مواضـع الوصسل: الوصـل لدفع الإيهام كما سـاه الخطيب(')، وهو مـا يعرف عند المتأخرين بـ "كمال

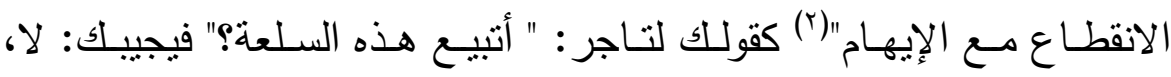
وعافالك الله" فهنالك كمال انقطاع لأن جملة " لا" خبربية لفظاً ومعنى، وجملة " عافـاك الله" خبريـة لفظـاً إنشـائية معنى، فالفصـل هنـا بـوهم خـلاف المـراد؛ إذ يتوهم أن المجيب يدعو بعدم العافيـة، فدفعاً لهذا التوهم يجب الفصـل ببن الجملتين. إن دفع التوهم في هذا النوع من الجمل مقصد أساسي من مقاصد الكلام يترتب عليه صحة المعنى وعدم التناقض، ووجود المناسبة بين أجزائه، وهم ما بحقق صحة النظم واستقامته، وبهذا نرى مدخل التوهم في هذا النوع من الجمل، وما بترتب على ترك العطف من توهم يفسد المعنى.

\section{الجامع بين الجملتين:}

لأجل أهمية الربط بين أجزاء الجمل، وملاحظة مـا بينها من مناسبات، نجد البلاغيين قد تصدوا للتوهم مرة ثانية، وهم بصدد الحديث عن الجامع بين الجملتين (r)، وأخص بالذكر هنـا " الجـامع الـوهمي، والخيـال"؛ لأن ملاحظة المناسبة لدفع التوهم في المعنى هي التي دعت إلى دراسـة أنواع الجامع بين الجمل، وهذا يدل على أن بحث "التوهم" بحنل مساحة كبيرة من باب الفصل والوصل. وقد ذكروا أن الوهمي: بأن يكون بين تصوريهما شبه تماثل، كلون

$$
\text { VT/r الإيضاح }
$$

(r) ويقابله من أحوال الفصل كمال الانقطاع بـلا إيهام بأن يكون بين الجملتين نباين تام

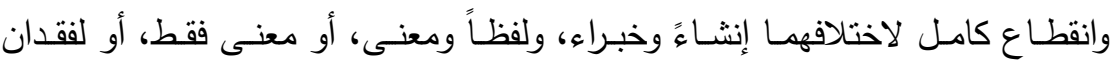

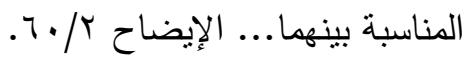

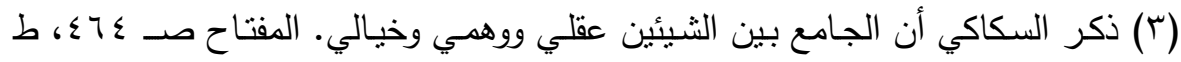

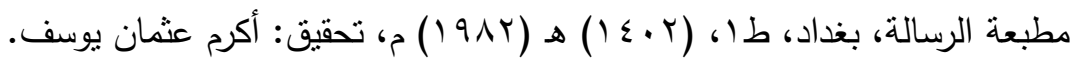


حوليتّ كليت اللغت العربيت بإيتاى البارود (العدد الثاني والثلاثون ـ المجلد الثالث) بياض ولون صفرة، فإن الوهم يبرزهما في معرض المنلين، وقد ذكروا من أمنثله: قول محمد بن وهيب:

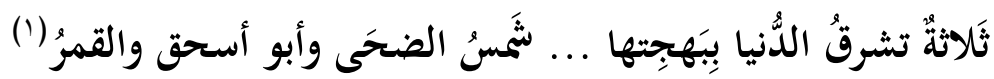

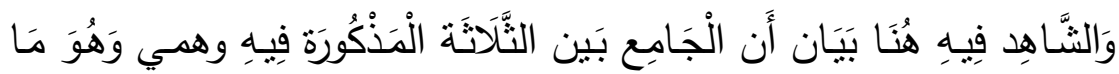
بَينهِا من شبه الثَّمَاثُل حمل الْوَهم على أَن بحتال فِي اجتماعها فِي المفكرة

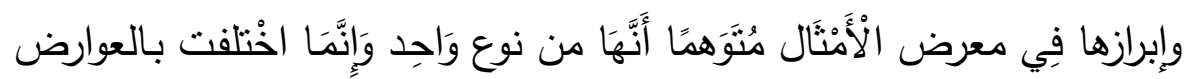

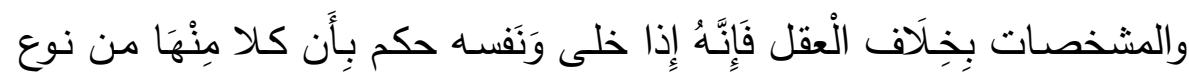
آخر وَانَّمَا اشتركت فِي عَارض هُوَ إثراق الأُنْيَا ببهجتها على أَن ذَلِك فِي أبي

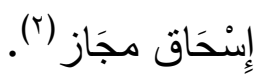
أمسا الخيالي: بأن يكون بين تصوريهما تقارن في الخيال سـابق، وأسبابه مختلفة، ولذلك اختلفت الصور الثابتة في الخيالات ترتبًا ووضوحاً، فكم صور تتعانق في خيال وهي في آخر لا تتراءي، وكم صورة لا تكاد نلوح في خيال وهي في غيره نار على علم. ولصاحب علم المعاني فضل احتياج إلى التتبيه لأنواع الجامع لا سيما الخيالي فان جمعه على مجرى الألف والعادة بحسب ما تتعقد لأسباب في ذلك كالجمع بين الإبل والسماء والجبال والأرض في قوله

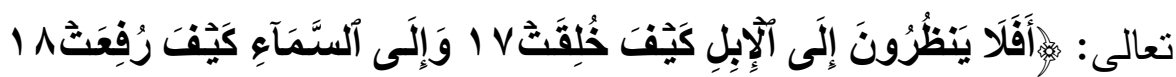

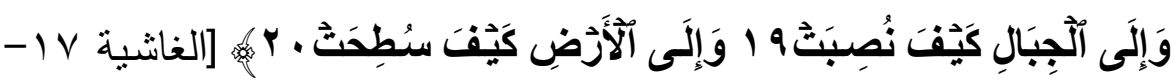
• ץ] بالنسبة إلى أهل الوبر فإن جل انتفاعهم في معاشهم من الإبـل فتكون عنايتهم مصروفة إليها، وانتفاعهم منها لا يحصل إلا بأن ترعى ونترب وذلك بنزول المطر فيكثر تقلب وجوههم في السماء ثم لابد لهم من مأوى يؤوبهم وحصن يتحصنون بـه ولا شيء لهم في ذلك كالجبال ثم لا غنى لهم لتعذر طول مكثهم في منزل عن التتقل من أرض إلى سواها فإذا فنس البدوي في

(1) البيت لمحمد بن وهيب من البسيط يمدح المعتصم، وأبو إسحاق كنيته.

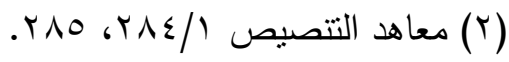


حوليتّكليت اللغت العربيت بايتتاى البارود (العدد الثاني والثلاثون ـ المجلد الثالث)

خيالـه وجد صـور هذه الأثـياء حاضـرة فيـه على الترتيـب المـذكور بخـلاف

الحضري فإذا نالا قبل الوقوف على ما ذكرنا ظن النسق لجهله معيبًا.

فالجـامع الوهمي ضـابطه أن الجمع فيـه بين الثيئين اعتباريًا غير محسوس

بإحدى الحواس الظاهرة، أمـا الخيالي فيكون الجمع فيه بين الثيئين اعتبارياً

مسنداً إلى إحدى الحواس الظاهرة(').

ونلمح في طيات كلام الخطيب إثـارات دقيقة إلى أهمبة الخيال ودوره في

إدراك المعاني، وعلاقة ذلك بـالوهم، فضـلاً عن الإشـارة إلى اتسـاع مجـالات الخيـال واختلافهـا مـن شـخص لآخـر بحسـب الاسـتعداد وقـوة الملكـة، وهـي إثارات دقيقة تلتقي مع ما وصلت إليه النظريات النقدية الحديثة التي تتحدث عن الخيال ودوره في النص، وعناصر الخيال ، وكيف تتداعى في النص بما بينها من علاقات التشـابه أو التضـاد أو شبه التضـاد(؟). وهذه التفاصيل كلها ما بتصل بحقيقة التوهم والتخييل، وأثز ذللك في المعنى، ولذللك نلمح ما ذكره حول أهمية معرفة صاحب المعاني لأنواع الجامع وخاصة الخيالي منها.

الاحتراس (r) : (r)

$$
\begin{aligned}
& \text { (1) بغية الإيضاح VA/r. V } \\
& \text { (r) الإيضاح (r) }
\end{aligned}
$$

(r) أكثر علماء المعاني جعلوا التكميل والاحتراس شيئا واحدا، والمحققون من المتأخرين وأصحاب البديعيات على أن كلا منهما نوع برأسه. فإن التكميل يرد على المعنى التام فيكمل أوصافه، والاحتراس يرد على المعنى الموهم خلاف المقصود، فيدفع ذلك الوهم. هذا وقد جعل ابن رشيق الاحتراس نوعاً من التتميم وسوى بينهما، لكن جعلهما في باب واحد غير سـائغ كما يرى ابن حجـة الحمـوي. والخطيب القزويني قد جعل التكميل بمعنى الاحتراس في التسمية. ابن أبي الإصبع، تحرير التحبير صـ 0 ك ب، ط المجلس الأعلى للثؤون الإسـامية، القاهرة، تحقيق: حفني شرف، والعددة في محاسن الثعر الثر

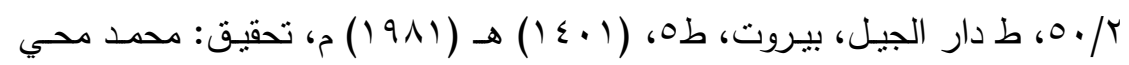

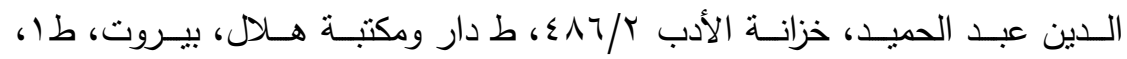

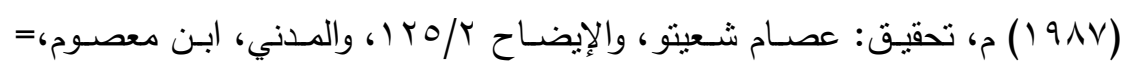


حوليت كليت اللغت العربيتّ بإيتاى البارود (العدد الثاني والثلاثون ـ المجلد الثالث) ونلتقي مـع التوهم عند البلاغيين في بحث " الاحتراس" من أنواع الإطناب، وقد ذكروا في تعريفه" أن بؤتى في كلام بوهم خلاف المقصود بما بدفعه"(')، وقد ذكروا أنه ضربان: ضرب يتوسط الكلام، كقول طرفة:

فَسَقى دِيارَكِ -غيرَ مُفْسِدِهَا-

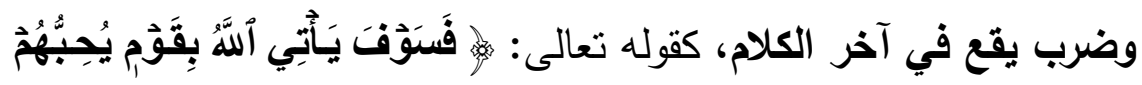

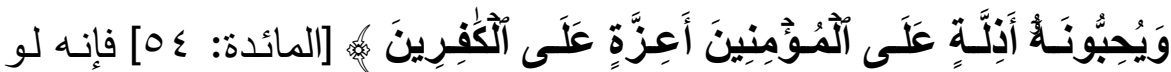
اقتصر على وصفهم بالذلة على المؤمنين لتوهم أن ذلتهم لضعفهم فلما قيل أعزة على الكافرين علم أنها منهم تواضـع لهم ولذا عدى "الذل" بـ "على" لتضمينه معنى العطف كأنه قيل عاطفين عليهم على وجـه التذلل والتواضـع ويجـوز أن تكـون التعديـة بعلى لأن المعنـى أنهـم مـع شـرفهم وعلـو طبقتهم وفضلهم على المؤمنين خافضون لهم أجنحتهم"(r). هذا وقد فرق بعضـهم بين الاحتراس والتكميل والتتمسيم: بأن المعنى قبل التكميل صحيح ثام ثم يأتي التكميل بزيادة تكمل حسنه إما بفن زائد أو معنى،

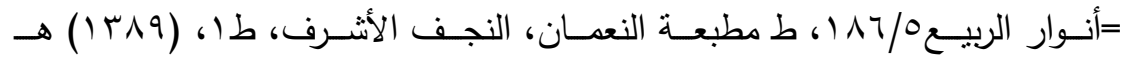
(1979 (197) ) م، تحقيق: شاكر هادي شكر

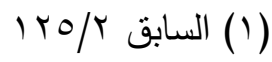

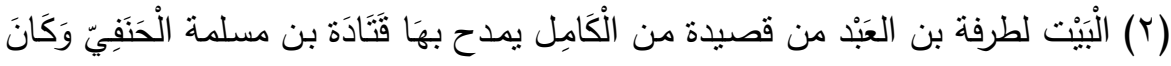

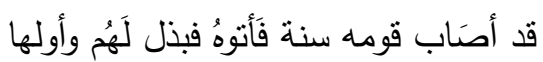

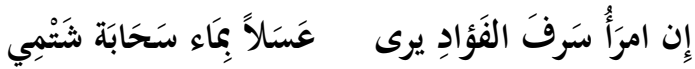

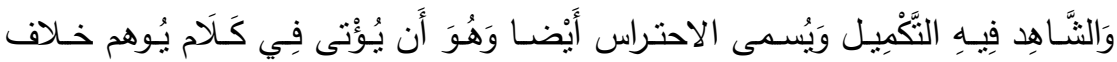

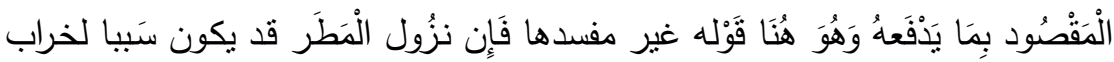

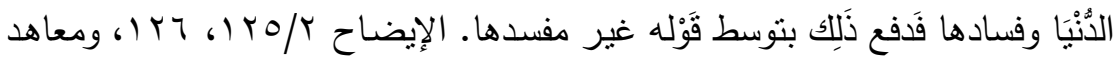

$$
\begin{aligned}
& \text { التتصيص // } \\
& \text { الإيضناح ro/r I I ا. }
\end{aligned}
$$


حوليتّ كليت اللغت العربيت بإيتاى البارود (العدد الثاني والثلاثون ـ المجلد الثالث)

والتتميم يأتي لتتميم نقص المعنى ونقص الوزن معًا، والاحتراس إنما هو لدخل

يتطرق إلى المعنى وإن كان تامَّا كاملاً ووزن الثعر صحيحًا"('). وهنا نرى التوهم يدخل في باب "الاحتراس" لئلا يتسرب إلى مخيلة السامع أن هناك نقصاً في المعنى أو قصوراً في الوصف. وهذا الفن من المعاني له مدخل كبير في إيضاح المعاني، ودفع ما يدور حولها في الأوهام، وله أمثلة من القرآن والسنة، وكلام العرب شعره ونثره.

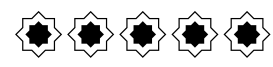




\section{المبحث الثاني}

\section{التوهم في صور الببيان}

لـ تقف إثـارات البلاغيين إلى التوهم عند مسـائل المعـاني وفنونـه، بـل امتدت لتأخذ بعداً آخر في دراسـة صور البيان وأنماطها، وبيان ما وراء هذه الصور من معانٍ تزتبط بالخيال الذي هو أحد الأصول التي يستتد إليها بحث التوهم. ولقد كان للبلاغيين عبارات دقيقة وتحقيقات مهمة في هذا الباب كثفوا من خلالها عن علاقة الوهم بالخيال، وأثر ذلك في تتكيل الصورة، كما فرقوا بين الأمور الوهمية والخيالية. وهي إثارات دقيقة تدل على إلمامهم بدور هذها وائ الظاهرة في تشكيل المعنى، والتعبير عن النفس.

\section{التشبيه الوهمي:}

تكلم البلاغيون عن هذا النوع من التشبيه وهم بصدد الحديث عن طرفي التشبيه "الحسي والعقلي"، و "التثبيه الوهمي"، وهو ما ليس مدركاً بشيء من هن الحواس الخمس الظاهرة مع أنه لو أدرك لم يدرك إلا بها. كما في قول امرئ وهئ

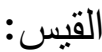

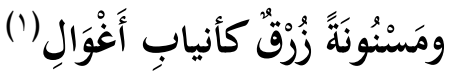

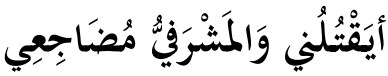

(1) البيت من الطويل، وهو من قصيدة لامرئ القيس، ومطلعها:

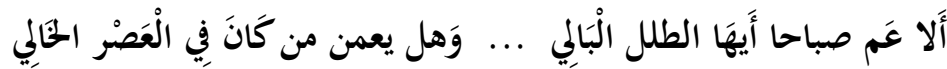

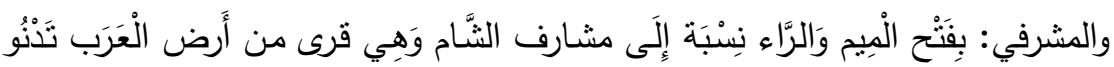
من الرِِّف مِنْهَا السيوف المشـرفية. والمسنون: المحدد المصقول. وَوصف النصـال

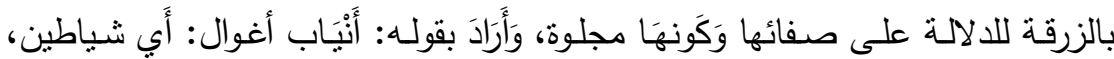

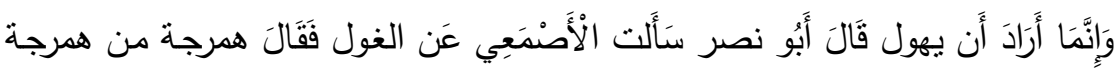

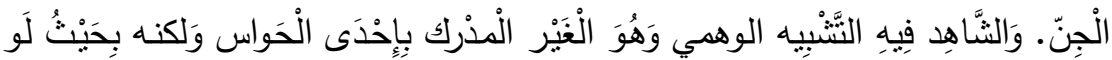

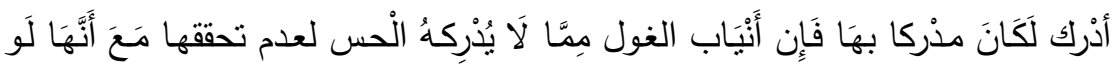

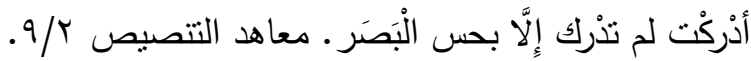


حوليت كليت اللغت العربيت بإيتاى البارود (العدد الثاني والثلاثون ـ المجلد الثالث)

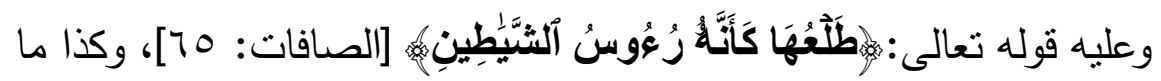
يدرك بالوجدان: كاللذة والألم والثبع والجوع وأمسا وجهـه فهو المعنى الذي

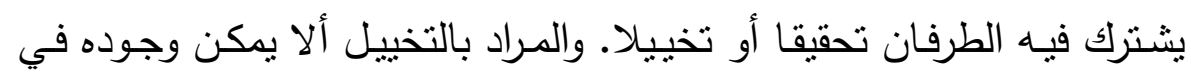
المشبه به إلا على تأويل كما في قول القاضي التنوخي:

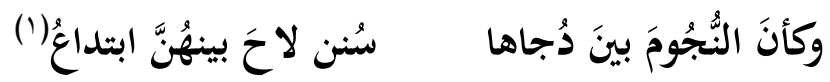

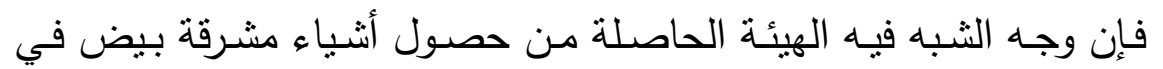
جوانب شيء مظلم أسود فهي غير موجودة في المشبه بـه إلا على طربق

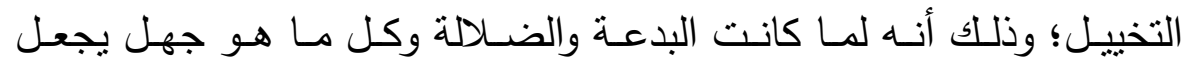

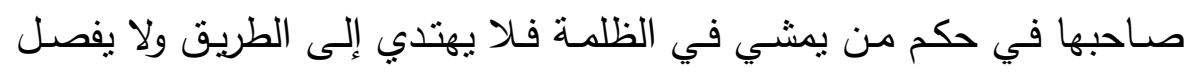
الثيء من غيره فلا يأمن أن يتردى في مهواة أو يعثر على عدو قاتل أو آفة

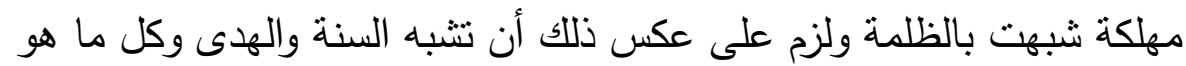

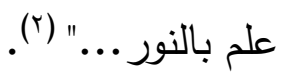
وهذا النوع الذي سموه بـ "الكوهمي" جعلوه في الأمور العقلية وغيرها، أمسا

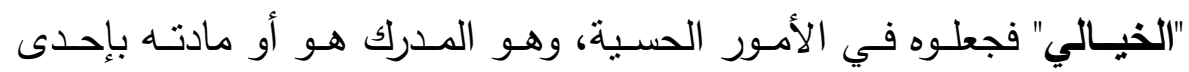

(1) البيت من الخفيف من أبيات، وأولها:

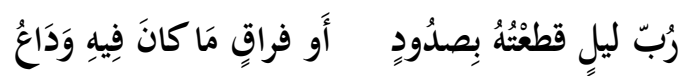

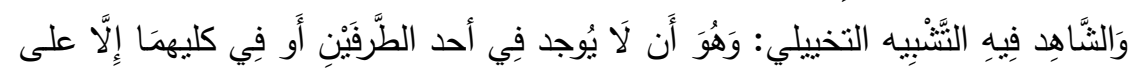

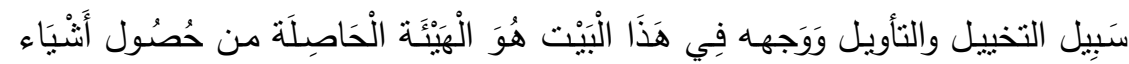

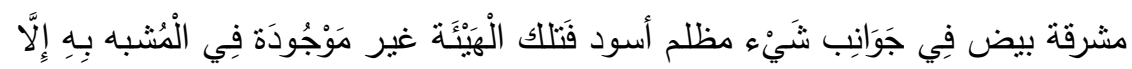

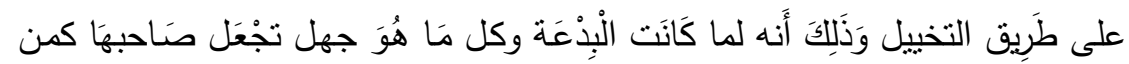

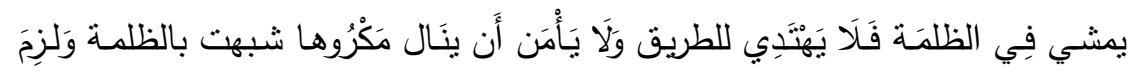

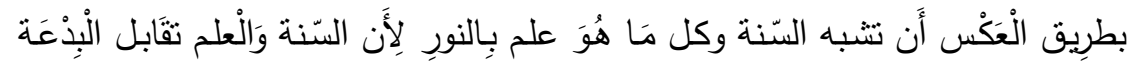

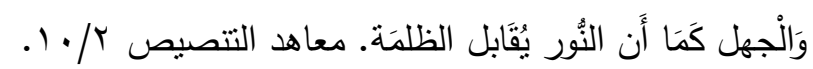


حوليتّ كليت اللغت العربيت بإيتاى البارود (العدد الثاني والثلاثون ـ المجلد الثالث)

الحــواس الخمسس الظـاهرة('). وذكـر الحلبـي أن "الـوهمي" قربـب مـن النـوع

المسمى بـ "التشبيه الخيالي" (؟).

الفرق بين الأمور الخيالية والأمسور الوهمبـة: نرى لبعضهم كلاماً دقيقاً على الفرق بين الأمور الخيالية والأمور الوهمبة، فالأمور الخيالية التشبيه فيها على قدر ما يرى في الخيال، كأن يتخيل شبحاً من بعيد فيظنه إنساناً، وإذا تخيله ضـئيلاً شبههه بالقلم...أمـا عن الأمسور الوهميـة فكأن يتوهم الواحد منـا فراق ما يألفه فيشبهه بتقطيع الجسم، ووخز الثفار • وعن الفرق بين الأمور الخيالية والوهمية يقول العلوي: "والتفرقة بين الأمور الخيالية والأمور الموهومة هو أن الخيال أكثر ما يكون في الأمور المحسوسة، فأما الأمور الوهمية فإنما تكون في المحسوس وغير المحسوس مدـا يكون حاصـلا في التوهم وداخـلا

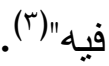

ونرى عبد القاهر الجرجاني يثير إلى سر الجمال في هذا النوع الخيالي، وبرى أنه قد كساه روعة الإعجاب، وصبغته صبغة الحسن؛ لأن الثيء كلما كان أدخل في الـوهم والخيـال كلمـا كـان أبعـ في مرمسى الحسـن والجمـال، فالثيء كلما كان نادر الوقوع، ولا يطمع أن يدخل تحت الرؤبة ولا بعهد منله

(1) ومثلوا له بقول الثناعر : (1)

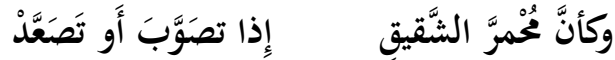 أعلامُ ياقوتٍ نشرن عَلى رماح من زَبَرْجَدْ}

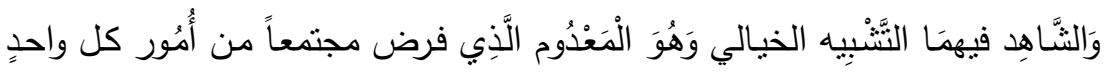

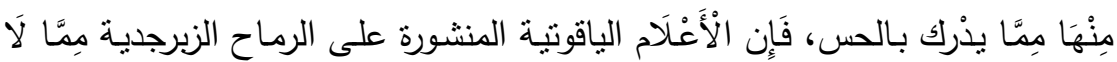

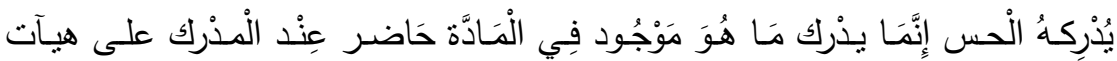

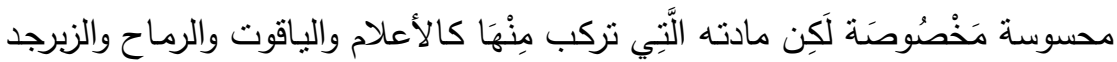

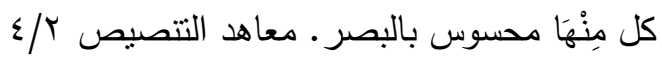

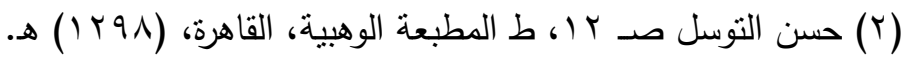

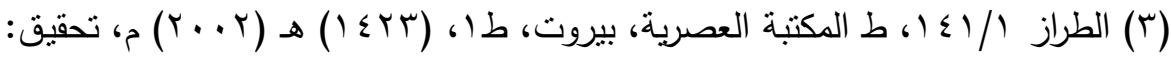


حوليتّكليت اللغت العربيت بايتتاى البارود (العدد الثاني والثلاثون ـ المجلد الثالث)

كلما عز ولطف حتى يبعد عن العيون، ويكون وجوده ممتتعاً أصـلاً حتى لا لإنتاك

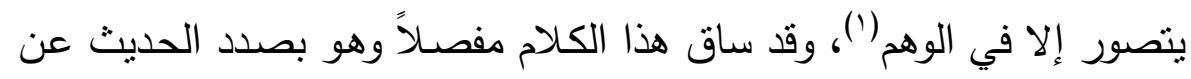
ضابط النشبيه المركب، وكثرة وجوده وندرته.

وهي إثـارات دقيقة نرى فيه لمحات إلى ما بدور في خفايا النفس وبمس وجدانياتها، وتدل على إدراكهم لـدور الخيـال والـوهم، وأثرهمـا في صـياغة المعاني، وكيف نتشكَّل هذا الأمور الوهمية وتترتب في النفس، وهذا الكلام يلتقي مع أحدث ما وصلت إلبه النظريات البلاغية والنقدية حول دور الخيال وأثره في العمـل الأدبـي، وكذللك القوة الوهميـة في العقل، وأثرهـا في تشكيل المعـاني، وتصـوبرها. وهذه كلهـا آفـاق متراحبـة تجتمـع في تكوين وتشـكيل

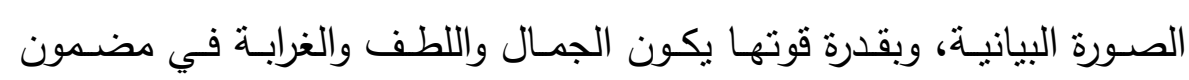
الصورة.

\section{أغراض التشبيه، وما يعود إلى المشبه به منها:}

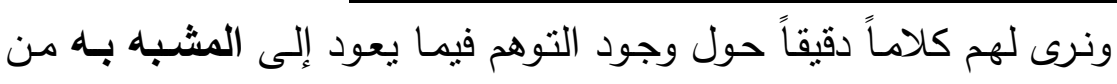
أغراض، وذلك إنما يكون في "التشبيه المقلوب" وهو أن يكون الأمر بالعكس:

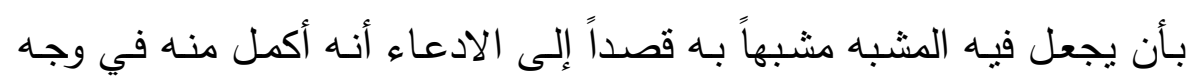
الثـبه"(r). كمـا ذكر النـوبري ت (سT/) في تعريفـه: "أن تقصـد على عـادة التخييل أن توهم في الثيء القاصر عن نظيره أنه زائد فنشبه الزائد به"(r). وهذه التعربفات السابقة عبارتها متقاربة، وكلها تدور حول عكس التشبيه بأن يصبح المشبه بـه مشبهاً، والمشبه مشبهاً بـه بادعاء أن الثاني أكمل من وهن وهار الأول في وجهه الثبـه. فقد بقصد الثـاعر على عـادة التخييـل أن يـوهم في

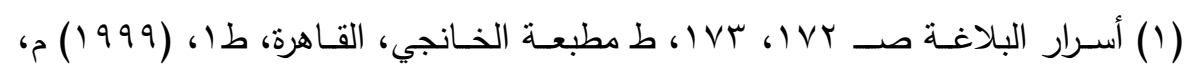

تحقيق: محمود شاكر •

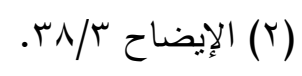

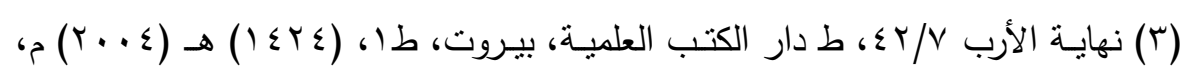


حوليت كليتا اللغت العربيت بإيتاى البارود (العدد الثاني والثلاثون ـ المجلد الثالث)

الثـيء هـو قاصـر عـن نظيـره في الصـفة أنـهـ زائـد عليـهـ في اسـتحقاقها، واستيجاب أن يجعل أصـلاً فيها فيصـح على موجب دعواه وسـرفه أن يجعل الفرع أصلاً. وإن كنا إذا رجعنا إلى التحقيق لم نجد الأمر يستقيم على ظاهر ما يضع اللفظ عليه ومن أمثلته البيت المشهور لمحمد بن وهيب:

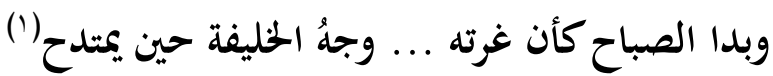

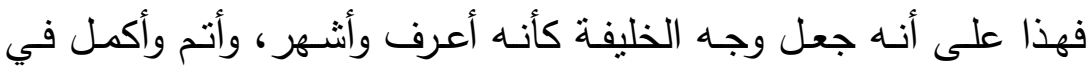
النور والضـياء مـن الصباح، فاستقام لـه بحكم هذه النيـة أن يجعل الصباح فرعاً، ووجه الخليفة أصلاً، وأنقل هنا عبارات عبد القاهر الجرجاني في تحليل النتبيه في البيت، وكيف أبرز جانب التوهم للمبالغة في المعنى، يقول: "واعلم أن هذه الدعوى وإن كنت نراها تشبه قولهم: "لا يدرى أوجهه أنور أم الصبح، وله

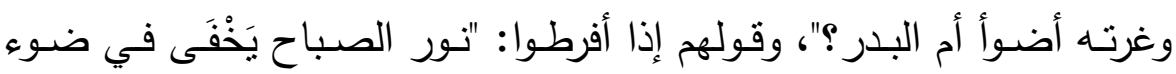

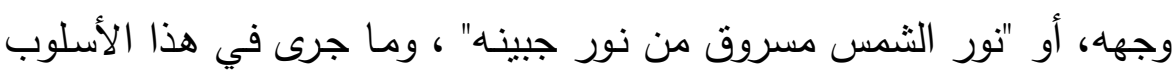

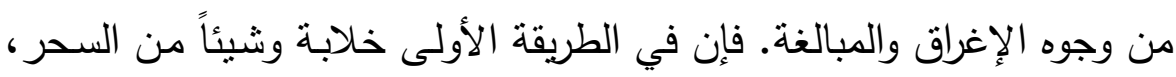

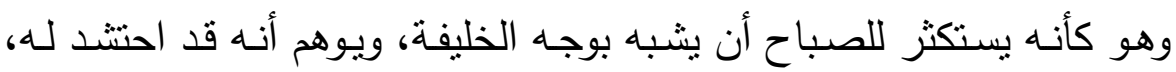
واجتهد في طلب شيء يفخم به أمره.

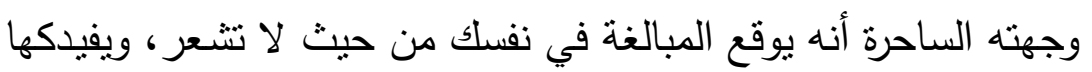
من غير أن يظهر ادعاؤه لها ؛ لأنه وضع كلامه وضع من يقيس على أصل متفق عليه ، ويُزجِّي الخبر عن أمر مسلم لا حاجة فيه إلى دعوى ، ولا إثفاق

(1) والغرة في الأصل البياض في جبهة الفرس، وقد استعيرت لبياض الصبح، والمراد

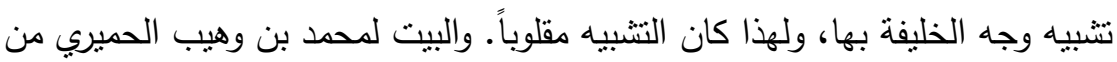
الكامل بمدح بها المأمون، ومطلعها:

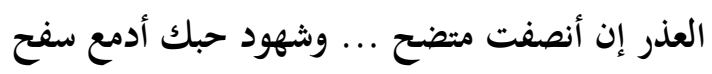

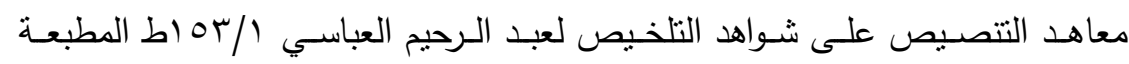

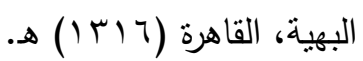


حوليتّ كليت اللغت العربيت بإيتاى البارود (العدد الثاني والثلاثون ـ المجلد الثالث)

من خلاف مخالف وإنكار منكر ، وتجهم معترض، وتهكم قائل: "لم" ؟، "ومن أين للك ذلك" ؟ والمعاني إذا وردت على النفس هذا المورد كان لها ضرب من السرور خاص، وحدث بها من الفرح عجيب، فكانت كالنعمة لم تكدرها المنة،

والصنيعة لم ينغصها اعتداد المصطنع لها('). ونلمـح أن الهدف الكامن مـن وراء هذا التوهم هو المبالغـة في إيهام أن المشبه [ المشبه به] أكمل وأبلغ في الصفة من المشبه، وهو ما يجري في كلام الثعراء، لكن على ما جرت به عادة العرب في كلامها حتى يكون مقبولاً، وله ضوابط قد ذكرها البلاغيون ليس هذا موضع ذكرها(r). الاستعارة الوهمينت: ومـا زلنا في بحث التوهم في الصور عند البلاغيين؛ حيث أشـاروا إلى التوهم أيضاً، وهم بصدد الحديث عن "الاستعارة الوهمية"، وذكروا في تعريف الاسـتعارة الخياليـة الوهميـة:" هـي أن تسـتعير لفظــا دالا على حقيقـة خياليـة تقدرها في الوهم، ثم تردفها بذكر المستعار له، إيضاحا لها وتعريفا لحالها كما

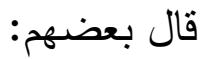

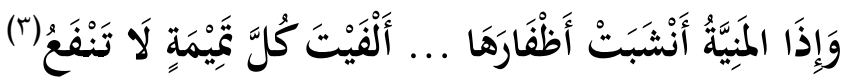

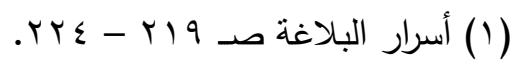

(r) التتبيه المقلوب بين القبول والرد، دراسة بلاغية في تراث أهل العلم صـ \، 1 لكاتب السطور ، بحث منشور بمجلة كلية اللغة العربية - أسيوط - جامعة الأزهر - العدد برد بله

$$
\cdot r_{r} \cdot 19-(r \Lambda)
$$

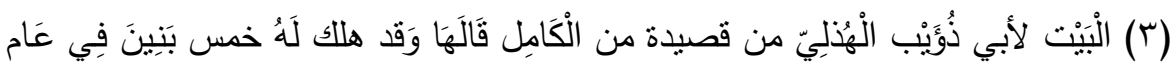

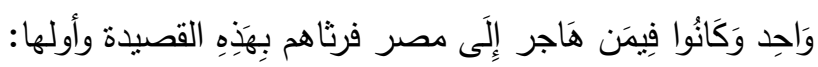

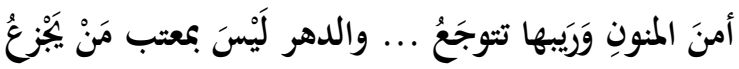

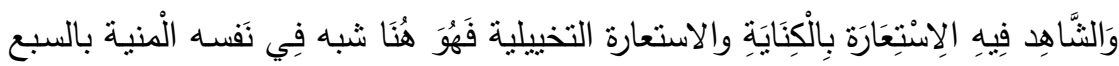

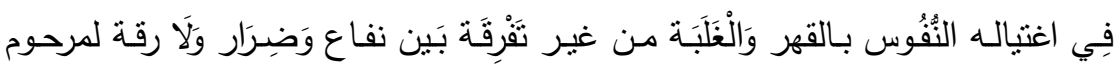

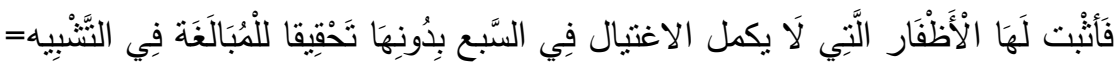


حوليتة كليت اللغت العربيت بإيتاى البارود (العدد الثاني والثلاثون ـ المجلد الثالث)

ومـن الخياليـة قـولهم: "فـلان أنشـبت المنيـة فيـه مخالبهـا" كـان تخيـيلا

للاستعارة، لأنـه لما شبه المنية بالسبع في عدوانها وتضريتها على الإنسان،

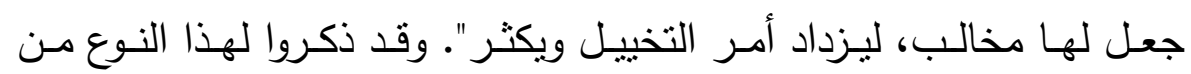
الاستعارة أمنلة كثيرة من القرآن والثعر ('). والاستعارة التي أشـاروا إليها هي لئردي الاستعارة المكنية التخييلية التي يطوى فيها ذكر المستعار منه أي المشبه بـه، ويذكر فيها المستعار لـه، أي المشبه، وسميت مكنيـة لأن المشبه بـه يطوى لإنه ويرمز إليه بلازم من لوازمه، ويسند هذا اللازم إلى المشبه، وإثبات لازم المشبه

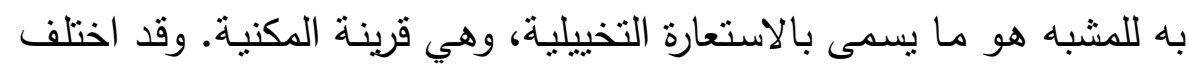
البلاغيون في تحديد مفهوم الاستعارتين " المكنية والتخييلية" ، فيرى جمهور البلاغيين أن المكنية: هي لفظ المشبه المستعار في النفس للمشبه، والمحذوف المـلول عليـه بثـيء مـن لوازمـه، و التخيليـة: هـي إثبـات لازم المشـبه بـهـ

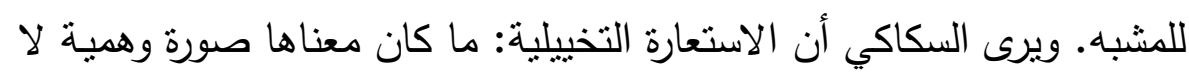

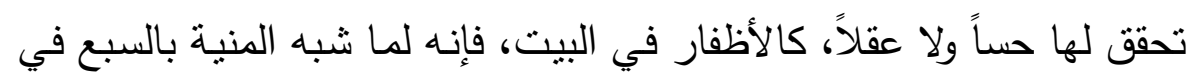
الاغتيال أخذ الوهم في تصورها بصورته، فاخترع لها صورة الأظفار ، ثم أطلق عليها أظفار السبع"(؟). فهو يرى أن هذه الاستعارة لا تحقق لها إلا في مجرد

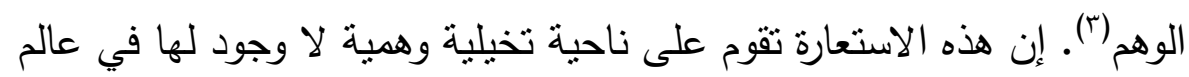

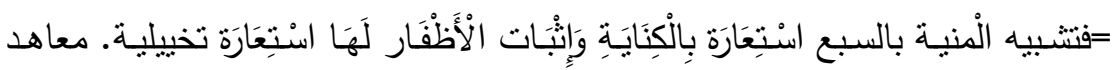

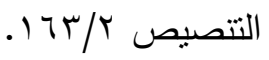

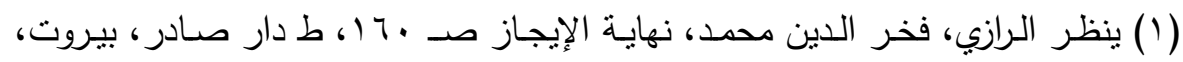

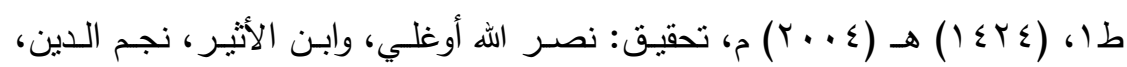

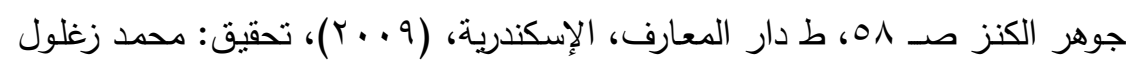

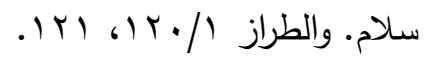

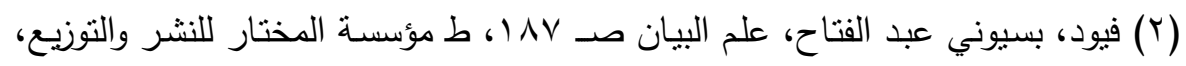

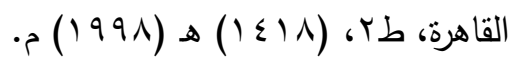

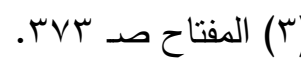




\section{التوسم في الدرس البلاغي "فنونه وخصائصه"}

حوليتّ كليت اللغت العربيتّ بإيتاى البارود (العدد الثاني والثلاثون ـ المجلد الثالث)

الواقع أو في عالم الحس، فالاستعارة المكنية بما فيها من جانب التوهم والتخيل تبـث الحياة في المعنويات، وتفرض الحياة والحركة على الجمادات، وتصور أموراً من الوجدانيات في صسورة محسوسـة تتقها من عالم الخيال والوهم إلى عالم الحس والواقع . وهنـا يمكن سـر الجمال في هذا النوع مـن الاسـتعارة ؛ ولذلك يتسابق إلبها الثعراء والأدباء ليعبروا من خلالها عن وجدانبات النفس، وانزباحاتها، وهذا أبضـاً يلتقي مـع أحدث نظريـات النقد والتلقي، ومـا تتحدث عنـه مـن دور البلاغـة في التعبيـر عـن تجربـة الثـاعر وانحرافاتهـ النفسية ومعاناته، فالاستعارة الوهمية بقربنتها وسيلة للتعبير عن النفس ومكنوناتها. $\{\hat{1} \leqslant\{$ 


\section{المبحث الثالث}

\section{التوهم في أساليب وفنون البديع}

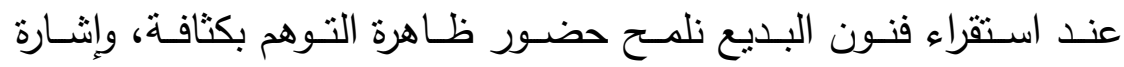
البلاغيين إلى وجود هذه الظاهرة في أكثر من فن من فنونه، وعلى رأس هذه

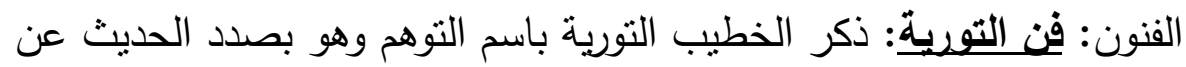
أضربها")، وكذلك نقل العلوي، وهو بصدد الحديث عن "التورية"(Y)، لكن اسم

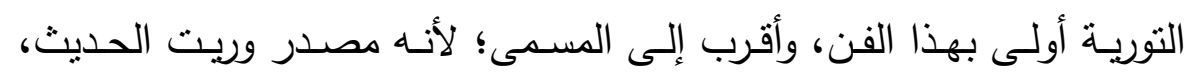

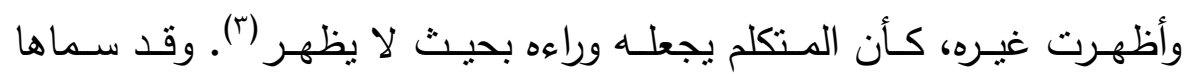
البلاغيون بـ "الإيهام ، والتوهم، والتخييل" لما فيها من جانب الخداع في ظاهر اللفظ، وقد عرفها البلاغيون " بأن يطلق لفظ له معنيان: قريب، وبعيد، ويراد البعيد منهما"(؛)، ولما في التورية من هذا التوهم والخداع عن المعنى الحقيقي البعيد بالمعنى القريب أفاض البلاغيون في بيان أسرارها لما فيها من الإيهام والتخييل، ونجد ابن حجة الحموي ت(مVV) هـ قد أفرد لها ما يقرب من مجلد من كتابه خزانة الأدب(0)، وألف فيها صلاح الدين الصفدي كتاب" فض الختام عن التورية والاستخدام"، وتعقبه ابن حجة في كتابـه " كثف اللثام عن وجـه التورية والاستخدام"؛ حيث وجده لم يحرر معنى التورية تحريراً دقيقاً، ولم يذكر أقسامها كاملة، فأراد أن يتم نقص الكتاب(ج)، وقد أفاض ابن حجة فئ في الكلام

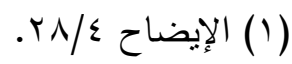

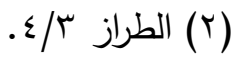

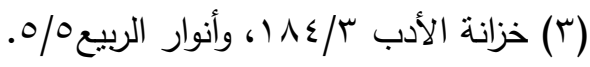

$$
\begin{aligned}
& \text { ( ) الإيضاح }
\end{aligned}
$$

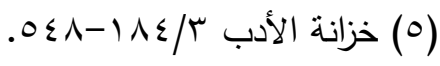

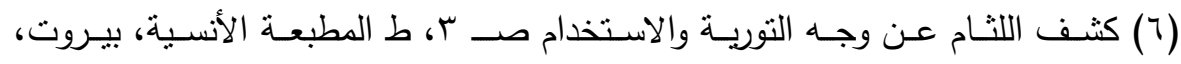


حوليتّ كليت اللغت العربيت بايتاى البارود (العدد الثاني والثلاثون ـ المجلد الثالث)

عن سر جمال التورية ولطائفها، وما وراءها من دقة المعنى وخفائه(')، ومن أمثلة التوربة الخفية قول الثاعر :

ملناهم طراً على الدهم بعدما ... . خلعنا عليهم بالطعان مالابساً فالتوريـة هنـا في كلمـة" الـدهم"، ومعناهـا القربـب المتبـادر إلى الذهن هـ الفرس الأسود، والمعنى الخفي البعبد المقصود هو القيد من الحديد، وقرينته ما ذكره من خلع الطعان عليهم حتى صـارت لهم كالملابس؛ لأنسه لا يصسح أن يكون المـراد حملهم على الأفراس، ففي قوله "حملنـاهم" يفيد استحكام التوهم حتى لا يـدرك عـدم إرادة القربـب إلا بتأمـل، وطـول نظـر (r)، فهنـا توهم في المعنى يحتاج إلىى ضـرب من التأمل، وإعمال الفكر ، والمقصود هنا الإثـارة إلى ما انتهى إلبه حالهم من الإذلال والقهر بطريق التوربة مبالغة في المعنى، فسلك هنا طريق الإيهام لهذا الغرض. وقد يكون التوهيم بوجود التوريـة في الكلام، ولكنها في الحقيقة غير موجودة، وذلك كقول ابن أبي الإصبع: رمى - ولا وِتر - عندي قوسُ حاجبه ... قبلي فقدَّرتُ أن القوسَ موتورُ فإن لفظة "موتـور" توهم أن فيها توربـة، وليسـت بتوربـة، لأن الصـحيح أن يقال: قوس مُوترَة لا موتورة، لأنها من فعل رباعي، والموتور هو الذي ثار لطلب وتزه، والوثز والترة والتار بمعنى"(r).

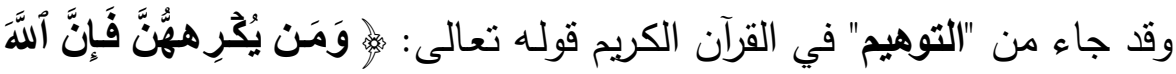

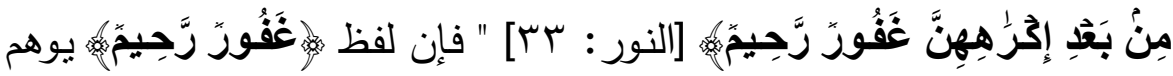
أن الغفران والرحمة للمكره لهن، وهما في الحقيقة لهن، وإنما ظاهر اللفظ يوهم الأول قبل التدبر "(ء)

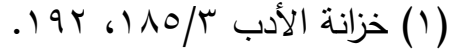

$$
\begin{aligned}
& \text { (r) بغية الإيضاح }
\end{aligned}
$$

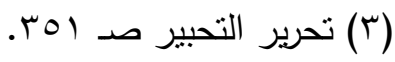

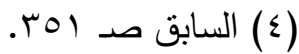


حوليت كليت اللغت العربيت بإيتاى البارود (العدد الثاني والثلاثون ـ المجلد الثالث)

وهذا من إيهام صرف اللفظ عن متعلقه('). وإشارة ابن أبي الأصبع إلى التوهم في التورية، وفي الآية الكريمة من إضافته لهذه الظاهرة، ونلمح هنا أن التوهم لا يكون في لفظ التورية فقط، بل يكون التوهم بوجود التوربة في الكلام أيضاً مع أنها في واقع الحال غير موجودة، وهذا من لطائف التخبيل والتوهم في هذا اللون من البيان.

إيـهام التضاد: ومن هذا الباب الخاص بالتوهم: إيهام التضاد في معنى اللفظ، وقد سماه الحموي "إيهام المطابقة "كما أن لهم إيهام التوربية(r)، وسماه المدني

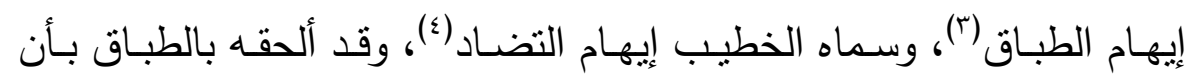
يجمع بين معنيين غير متقابلين عبر عنها بلفظين يتقابل معناهما الحقيقان، كقول دعبل الخزاعي:

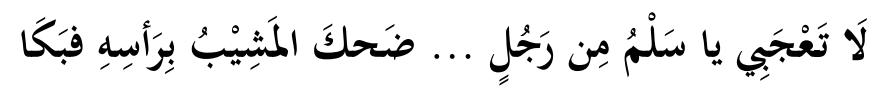
"فالضـحك هنـا مـن جهـة المعنى ليس بضـد للبكاء؛ لأنـه كنايسة عن كثرة

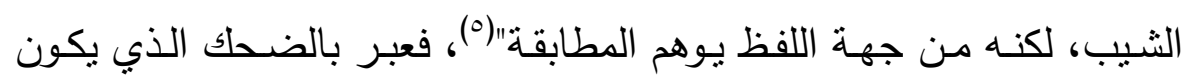
معناه الحقيقي مضـاد لمعنى البكاء(؟)، وهنا أوهم بالتضـاد في المعنى ليعبر

(1) قال ابن زاكور الفاسي: والفرق بين هذا النوع وما قبله في التورية: أن المصروف إلبه

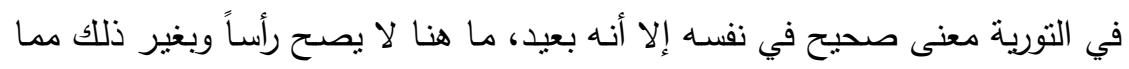
لا يجدي. الصنيع البديع في شرح الحلية ذات البديع صـ بr بـ، ط مطبعة النجاح

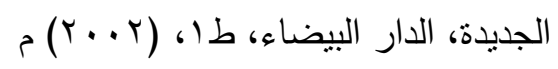

(Y) فهو يثير إلى جانب التوهم في المعنى هنـا كما في فن التوريـة السـابق، وهذا من

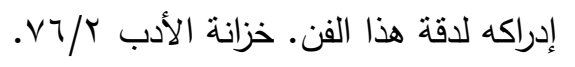

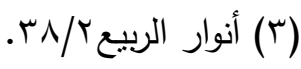

$$
\begin{aligned}
& \text { ( ) الإيضاح ع/11) }
\end{aligned}
$$

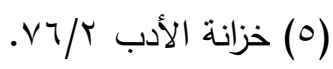

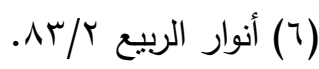


حوليتّ كليت اللغت العربيت بإيتاى البارود (العدد الثاني والثلاثون ـ المجلد الثالث)

عن كثرة ظهور الثيب وانتشاره في رأسـه، وتأثره بهذا الثببـ، فجاء التضـاد ليعبر عن هذه الحال الصعبة بين انتشار الثيب في الرأس وحزن صاحبه. ومن التوهم في المطابقة مـا ذكره زكي الدين بن أبي الإصبع في قول أبي

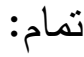

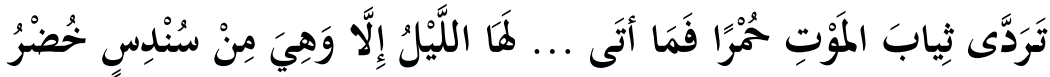
فإن في قوله:" حمر ، وخضر " يوهم أن ذلك طباق، وليس بطباق؛؛ إذ الأحمر

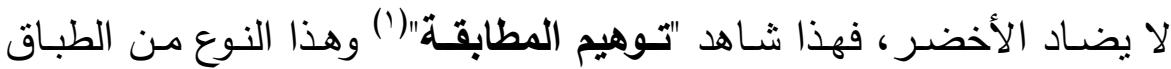
المسمى تدبيجًا(؟)، والمعنى " أنه لبس ثياب الدنيا وهى حمر من الدماء في الجهاد ثم استشهـ بعد ذلك فمـا أتى الليل إلا وقد خرجت روحهه من الدنيا وفارق الحياة وصار إلى الجنة لابسا ثياب السندس من عبقري الجنان، فكنى عن حال القتال بالثياب الحمر ، وكنى عن دخول الجنة بالثياب الخضر ، ففيه

$$
\text { من الحسن ما فيه"(r). }
$$

إيـهـام التتاسـبـ:سـماه الخطبـب القزوبني بهذا الاسـم، وألحقـه بـ "مراعـاة النظير" (؛)، وقدر رأى ابن بعقوب المغربي أن تسميته بهذا الاسم لتخيل الوهم فيه المناسبة باعتبار ما يتبادر كما مر في إيهام التضـاد(0) نحو قوله تعالى:

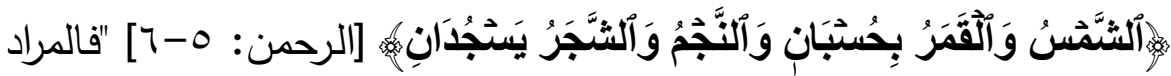
من النجم في الآبـة: النبات الذي لا سـاق لله، ولا مناسبة بينه وبين الثمس والقمر بهذا المعنى، وإنما بناسبهما إذا كان بمعنى الكوكب"(7). فالتتاسب بين

$$
\begin{aligned}
& \text { (1) تحرير التحبير صـ اهـ. } \\
& \text { (T) الإيضاح }
\end{aligned}
$$

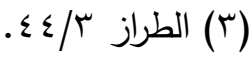

(§) وهو أن يجمع بين معنيين غير متتاسبين بلفظين يكون لهما معنيان متتاسبان، ولكنهما

$$
\text { غير مقصودين. }
$$

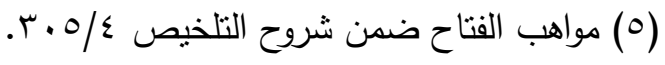

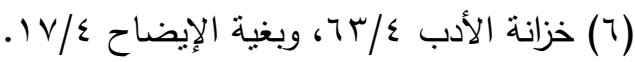


حوليت كليت اللغت العربيت بإيتاى البارود (العدد الثاني والثلاثون ـ المجلد الثالث)

الثمس والقمر ظاهر، ولم يقصد التمثيل باعتبارهما فقط، ولكن قصد التمثيل باعتبارهما مع النجم؛ إذ النجم في أصل معناه المتبادر يناسب الثمس والقمر لأنه يتبادر معهما في الخيال لكونه جسماً نورانياً سماوياً، ففيه باعتبار معناه

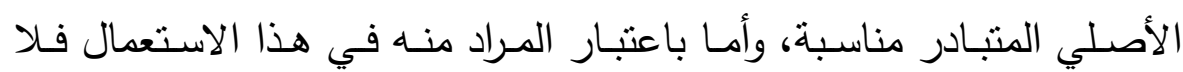
يناسبهما؛ إذ هو النبات الذي لا ساق لله، والثجر ما له ساق مما ينبت في

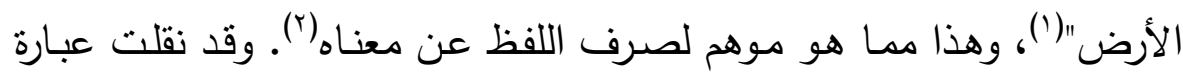
ابن يعقوب المغربي ليتضـح لنا من خلالها إثـارته إلى جانب المنبادر إلى الخيال والتوهم في المناسبة بين الثمس والقمر والنجم. وصورة التوهم هنا من روائع القرآن؛ حيث تلفت إلى خضـوع مـا في السماوات والأرض من شمس وقمر ونبات وشجر لقدرة الله يَّلْن.

\section{إيهاهر التوكيد:}

وهو أن يعيد المتكلم في كلامهه كلمة فأكثر مراداً بها غير المعنى الأول. حتى يتوهم السامع من أول وهلة أن الغرض التأكيد وليس كذللك؛ ولذللك سمي هري

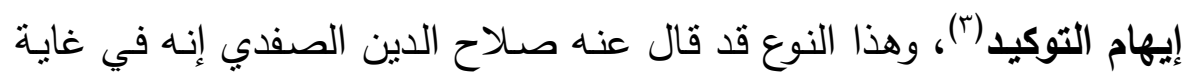
الحسن؛ حيث يظن السامع من أول وهلة أنه من باب التكرار إلى أن يعيره ذهنه ويتأمل معنى الثـاعر في ذلك فيرقص طربًا (؛). ومن ذلك في الثـعر:

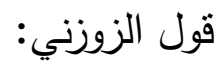

\section{ألا حل بي عجب عاجب تقاصر وصفي عن كنهه.}

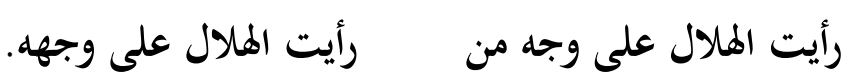

فالبيت الثاني يوهم أن الثطر الثاني منه تأكيد وتكرار للشطر الأول، ولكن في الحقيقة ليس تكراراً أو تأكيداً لله بل المعنى مختلف فيه. ومنه في القرآن

$$
\begin{aligned}
& \text { (1) مواهب الفتاح \&/0. ك. }
\end{aligned}
$$

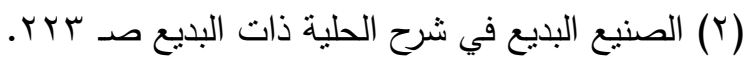

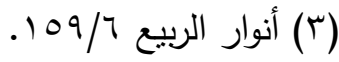

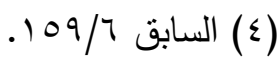


حوليتّ كليت اللغت العربيت بإيتاى البارود (العدد الثاني والثلاثون ـ المجلد الثالث)

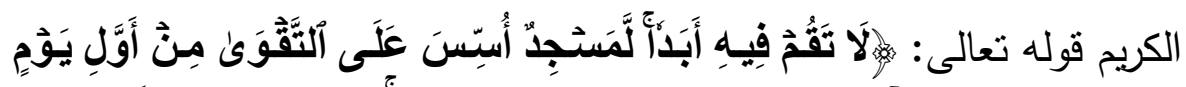

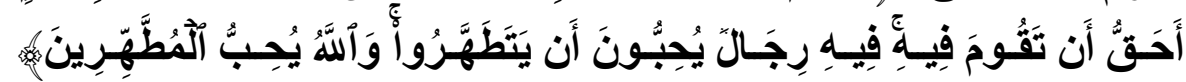

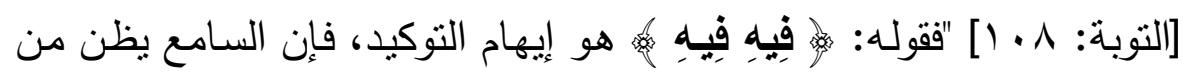
أول وهلة أن الثانية تأكيد للأولى وليس كذللك"(!). وهذا النوع من توهم التأكيد قد استخرجه زين الدين عمر بن الوردي، وسماه بهذا الاسم، وقال عنه صـلح الدين الصفدي إنه في غايـة الحسن، وذكر ابن معصوم المدني أنه لـ يقف عليه في شيء من كتب الفن(r)، وهذا بدل على إدراك البلاغيين لهذه الظاهرة في الجمل والتراكيب.

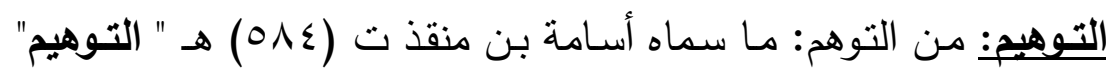

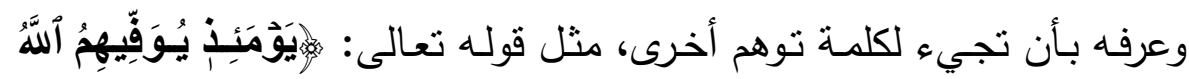

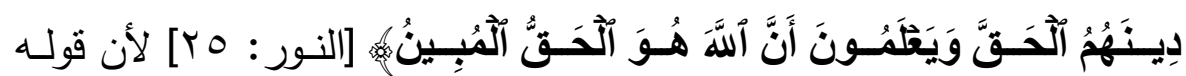
سبحانه: " يُوَفَِّهِهُ " بوهم من لا بحفظ دينهم الحق بـالفتح"(")، وذكر ابن أبي الإصبع في تعريفه: أن يأتي المتكلم في كلامه بكلمة يوهم ما بعدها من الكلام أن المتكلم أراد تصـحيفها، ومراده على خـلاف مـا يتوهمـه السـامع فيها، كقول المتتبي من المتقارب: وإن الفئام التي حوله ... لتحسد أرجلها الأرؤس

فإن لفظة الأرجل أوهمت السامع أن لفظة "الفئـام" بالقاف لا بالفاء، ومراد الثـاعر "الفئام" بالفـاء التي هـي الجماعـات، هكذا روى البيــ، والمبالغــة تقتضيه، إذ القبـام بالقاف يصدق على أقل الجمع مـن العدد. والفئام بالفاء: الجماعات، وأقل ما تكون كل جماعة أقل الجمع فمفهومها أكثر من مفهوم الأول، وما في ذكر القيام بالقاف من تعظيم الممدوح بقيام الناس على رأسـه

$$
\begin{aligned}
& \text { (1) أنوار الربيع 109/7. } \\
& \text { (Y) السابق 109/7) } \\
& \text { (r) البديع في نقد الثعر صـ 1Tـ. }
\end{aligned}
$$


حوليتّكليت اللغت العربيت بايتتاى البارود (العدد الثاني والثلاثون ـ المجلد الثالث)

حاصل في عجز البيت في قوله: لتحسد أرجلها الأرؤس فإن مفهوم ذلك قيام من عاد الضمير من أرجلها عليه"("). فالتوهم هنا حاصل بما جاء في عجز البيت من ذكر "الأرجل"، لكن ما جاء من ذكر "الفئام" بالفاء أدل على المعنى وعلى المبالغة فيه. هذا ولقد توسـع ابن أبي الإصبع في بحث "التوهيم" في كتابه " بديع القرآن" وذكر أنواعاً وأقساماً مختلفة من التوهم، لكن يبدو لي أنه قد دخلها شيء من التكلف في التقسيم والتفريع، وبعض هذه الفنون التي أشـار إلبها قد لا تدخل في باب التوهم، وقد أعرضت عن ذكرها لئلا ينشخل البحث.

عن قصده بالمناقشات والتعقيبات التي تصرفه عن قصده وغايته(r). الجناس: من صور التوهم: ما جاء في فن "الجناس"، وقد ألمع إليه عبد القاهر الجرجاني وهو بصدد الحديث عن التجنيس وأثره في المعنى، وضوابط ما هون بلاغته بأن يكون المعنى هو الذي يطلبه ويقود إلبه وليس العكس؛ حيث إن هناك أقساماً قد يتوهم في بدء الفكرة وقبل إتمام العبرة أن الحسن والقبح فيها لا لاعيه يتعدى اللفظ والجرس، ولكن إذا حققت النظر، وأمعنت الفكر وجدت أنه قد

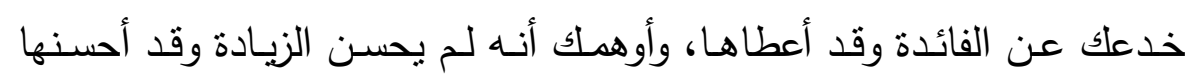

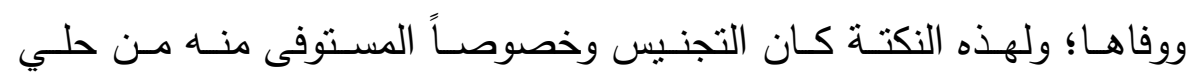

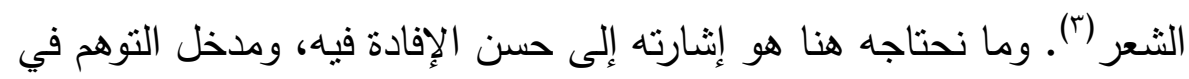
هذا اللون البديعي، وأنقل عبارته هنا حتى نصل إلى حديثه عن التوهم في المعنى، حيث يقول:" واعلم أنّ النكتة التي ذكرتها في التجنيس، وجعلتُها العّلةً

(1) تحرير التحبير صـ 9 §؟، هذا وهناك فرق بين التورية والتوهيم حيث إن التورية توهم وجهين صحيحين قريباً وبعيداً، والمراد البعيد منهما بينما بوهم التوهيم وجهين صحيح

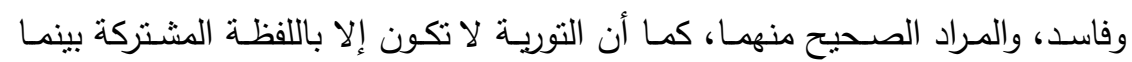

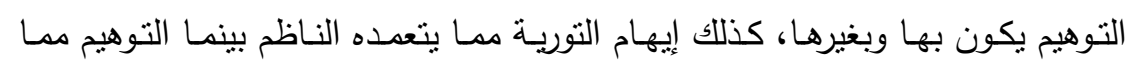

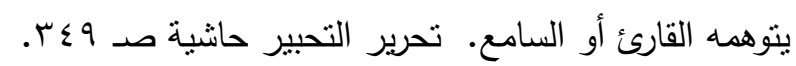

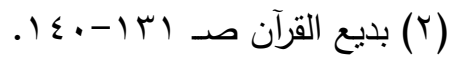

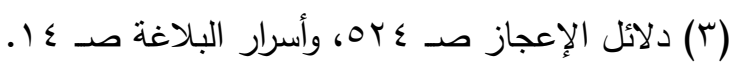


حوليت كليت اللغت العربيت بإيتاى البارود (العدد الثاني والثلاثون ـ المجلد الثالث)

في اسـتيجابه الفضـيلة وهـي حُسْـن الإفـادة، مــع أنّ الصـورة صـورةٌ التكريـر والإعـادة وإن كانـت لا تظهر الظهـورَ التـامَّ الـذي لا يمكـن دَفْعـهـ، إلا فـي المستوفَى المتفقى الصورة منه كقوله:

أو المرفُِّ الجاري هذا المَجْرَى كقوله: "أودَعانِي أمتنْ بما أوْدَعاني" (')، فقد يُتَََوََّر في غير ذلك من أقسامه أيضناً، فمما يظهر ذالك فيه ما كان نحو قول أبي تمام: - 20 - n

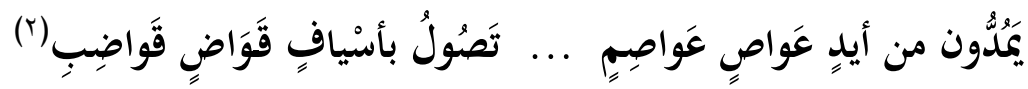
وذللك أنك تَّوهم قبل أن يردَ عليك آخرُ الكلمة كالميم من عواصم والباء من

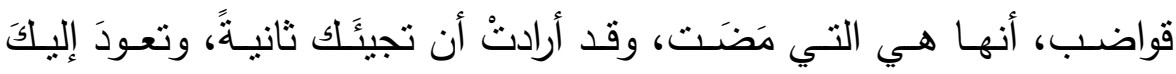
مؤكِدَةًَ، حتى إذا تمكن في نفسك تمادُها، ووعى سمعُك آخرَها، انصرفتََّ عن ظنّلك الأول، وزُلْتَتَ عن الذي سبق من التخيُّل، وفي ذلك مـا ذكرثُ للك من طلوع الفائدة بعد أنْ يخالطك اليأس منها، وحصسول الربح بعد أن تُنالََّ فيه حتى ترى أنه رأس المال. فأما مـا يقع التجانس فيه على العكس من هذا وذلك أن تختلف الكلمات من أوّلها كقول البحتري:

(1) جزء من بيت لأبي الفتح البستي من الخفيف، وأوله: ناَظراه فيما ناظِراه .... وقبله قوله: قيل للقلب ما دهاك أجبني ... قال لي بائع الفران فرابن

وفي البيتين ثلاثة مواضع للجناس؛ الأول: بين "الفراني" و "فراني" وهو من الجناس التام المستوفي؛ لأن الأولى اسـم، والثانيـة فعل. والثاني: بين "نـاظراه" "ونـاظراه" وهو مـن الجناس التام المستوفي؛ لاختلاف طرفيه بين الفعلية والاسمية، وهو محل الثاهد؛ لأن ناظراه الأولى فعل أمر مسند إلى ألف الاثتين، ومعناه: جادلاه وساءلاه، وناظراه الثانية

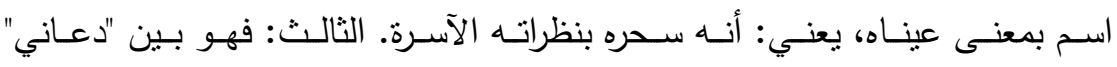

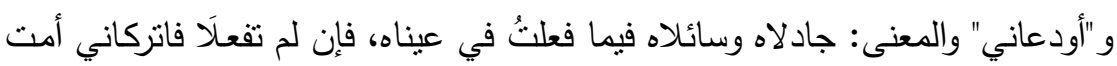

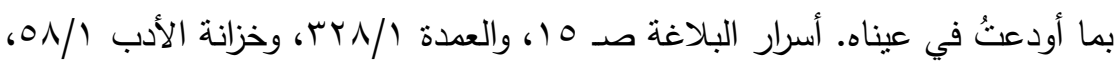

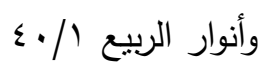
VY/ ع بنظر في معنى البيت: بغية الإيضاح (Y) 
حوليتّ كليت اللغت العربيت بإيتاى البارود (العدد الثاني والثلاثون ـ المجلد الثالث)

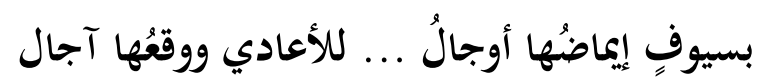

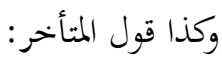

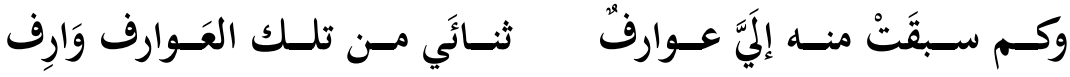

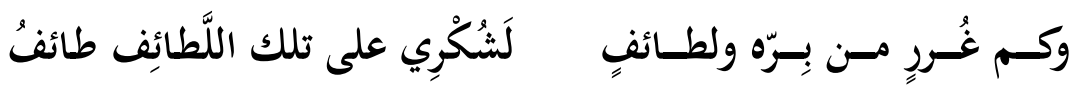

وذلك أنّ زيادة "عوَارِف" على "وارف" بحرف اختلاف من مبدأ الكلمة في

الجملة، فإنه لا يبعد كلَّ البعد عن اعتراض طرفٍ من هذا التخيُّل فيه، وإن

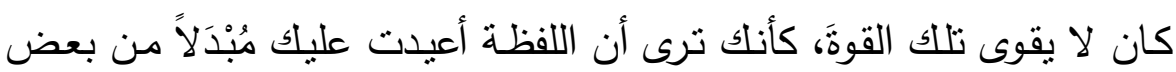

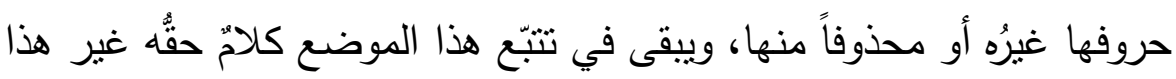
الفصل وذلك حيث يوضع. فالذي يجب عليه الاعتماد في هذا الفنّ، أن التوهُّم

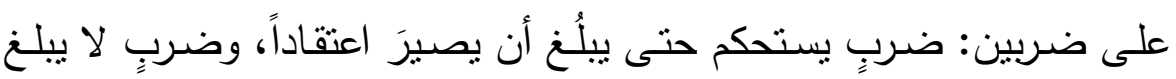
ذلك المبلـغ، ولكنه شيءٌ يجري في الخاطر، وأنت تعرف ذللك وتتصور وَزْنـهـ إذا نظرت إلى الفرق بين الثيئين يشتبهان الثَبََهَ التامَّ؛ والثيئين يشبه أحدُهما ونها بالآخر على ضرب من التقريب، فاعرفه"('). ونلمح هنا إثنارة عبد القاهر الجرجاني إلى مدخل التوهم في إدراك المعنى، فسر جمال الجناس في هذا اللون لما فيه من الخداع حول المعنى؛ حيث يُّتوهم أن اللفظة الثانية ستكون تكراراً وتأكيداً للأولى، ثم يأتي عنصر المفاجأة في

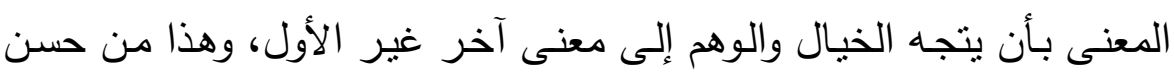
الإفادة وتأكيد المعنى في التجنيس، وأقوى مـا يكون ظهور هذا لـنهي التأكيد في الجناس المستوفى المتفق الصورة، وكذلك يكون في المرفو (؟).

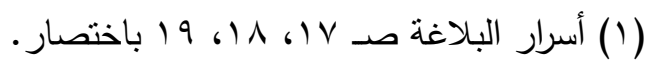

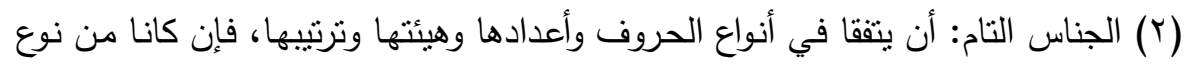

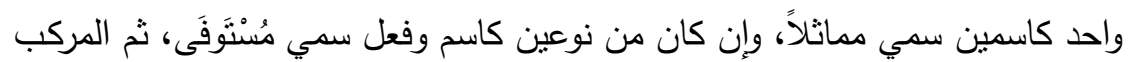

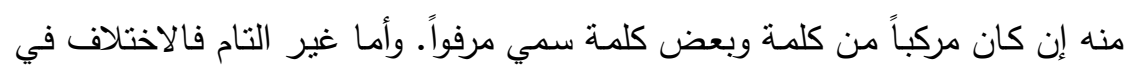

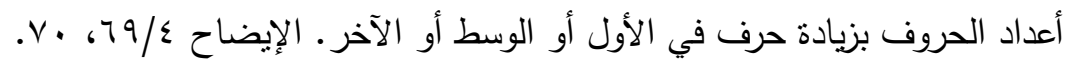


حوليت كليت اللغت العربيت بإيتاى البارود (العدد الثاني والثلاثون ـ المجلد الثالث)

وقد يكون في أنـواع من الجنـاس النـاقص بـأن يختلف بزبـادة حرف في

الأول أو الوسط أو الآخر، والمثال الذي أورده من غير التام بزيادة حرف في

الآخر أو في الأول ففيه أيضـاً من هذا التوهم والتخيل مـا سبق، ولكن ليس

بنفس الدرجة من القوة في التوهيم والتخييل. وهي إثـارات نلتقي مـع ما يسمى اليوم بمسـافة التوتز في النصسوص، وأثر ذلك على المنلقي وجذب انتباهـه للمعنى ، والتأثير فيه. ولقد زاد عبد القاهر كلامه بياناً بهذا التقسيم الذي ذكره للتوهم وما يستحكم منه حتى يصير اعتقاداً، وما يقل منه حتى يكون كالثيء يجري في الخاطر ، وهو هنا يصـف مسـتوبات التوهم والتخييـل في المعنى الكامن وراء التجنيس، وكلامه هنا دقيق جداً في هذا الباب، وهو في مضمونه يلتقي مـع آخر مـا دعت إلبـه النظريات الحديثة حول التلقي للنص، ومسألة التخييل في المعنى، ومسافة التوتز والانزباح، وغيرها من أشكال العدول عن مقتضى الظاهر من المعنى، وهو باب يضرب فيه التوهم بسهم كبير • أبواب أخرى من التوهيو: ذكر البلاغيون في الفنون السابقة الإشارة إلى معنى التوهم صراحة، وهناك أبواب متتوعة من فنون البلاغة لم يصرحوا فيها بلفظ التوهم، لكنها في المعنى تلتقي مـع هذا الفن، وتشـتمل على أغراضـه ومرامبه بحسب سياقات الكلام المختلفة. ويأتي على رأس هذا النوع: ما ذكروه حول خروج الكلام على خلاف المقتضى الظاهر (')، وذكروا من ذلك : وضع المضـمر موضـع المظهـر وعكسـه، والالتفـات بصـوره، والأسـلوب الحكيم، كرئ والتعبيـر عن المسـقبل بلفظ الماضـي، مثلهـه التعبير عنـه باسـم القاعـل، والقلب . وهذه الفنون من خروج الكلام على خـلاف مقتضى الظاهر عكساً

(1) وقد أثنار إلى ذلك الخطيب القزويني عند حديثه عن تخريج المسند إليه على خلاف

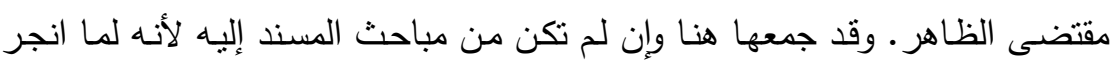
الكلام للحديث عن خلاف مقتضى الظاهر أورد عدة أقسام وإن لم تكن منه كما ذكر السعد. بغية الإيضاح //11/ 11 وما بعدها. 
حوليتّكليت اللغت العربيت بايتتاى البارود (العدد الثاني والثلاثون ـ المجلد الثالث)

لقصد السامع، أو للتنبيه على خطأ، أو لغير ذلك مما يدخل في باب التوهم على خلاف المقاصد والمعاني. ويدخل في باب التوهم من البديع: تأكيد المدح بمـا يشبه الذم، والتجريد، وحسن التخلص الذي سـماه الخطيب بـ " إيهام الاستطراد"("). وهي فنون بلاغية من المعاني والبديع تشتمل على أسرار بيانية ترتبط بالتوهم في بعض أمثلتها وصسورها، وقد تركت الإثـارة إلى تفاصسيلها خشية الإطالـة، وبمكن الرجوع إليها في مظانها(r) للوقوف على ما يدخل تحتها من أغراض، وما وراء

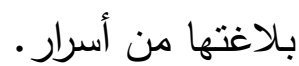

$\{\hat{-} \mathbf{0}\}$

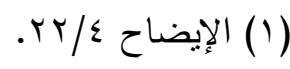

$$
\begin{aligned}
& \text { (Y) السابق //11/ } 11 \text { / وما بعدها. }
\end{aligned}
$$


حوليت كليتا اللغت العربيت بإيتاى البارود (العدد الثاني والثلاثون ـ المجلد الثالث)

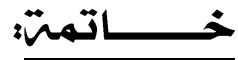

اتضح من خلال البحث معنى التوهم عند البلاغيين وعلاقته بالخيال، وأثره

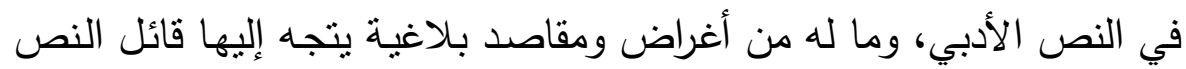

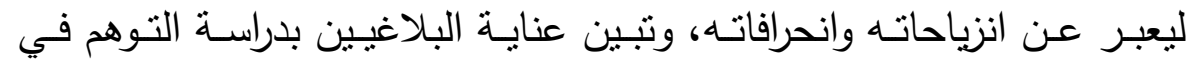
مساحة واسعة من فنون ومسائل البلاغة، مع إدراكهم لأثره في المعنى ، ودوره في التعبيـر عـن وجدانيات الـفس وخيالاتها، ومسـالكه في علـوم البلاغـة إنة

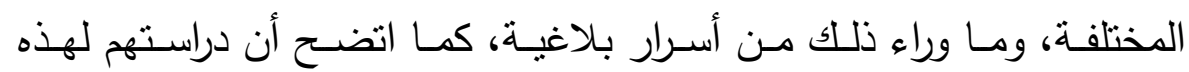
الظاهرة البلاغية تلتقي مع أحدث ما وصلت إليه النظريات النقدية والبلاغية حول " التوصيل"، ودور البلاغة وديناميتها في التعبير عن المعنى، وما يعرف بـ "نظريـة التلقي"، والتقاعل بين النص والقارئ، وعلاقة التوهم بالخيال، وأثر ذلك في المعنى. واتضح ما يشتمل عليه "التوهم" من خصائص ومعانٍ بلاغية تتصل بالنفس والتعبير عن خيالاتها. 
حوليت كليت اللغت العربيتّ بإيتاى البارود (العدد الثاني والثلاثون ـ المجلد الثالث)

\section{ثبت المصادر والهرايج}

القرآن الكيريه

- أسرار البلاغة، عبد القاهر الجرجاني، ط مكتبة الخانجي، القاهرة، طا،

• (1991) (199)

- أنوار الربيع في أنواع البديع، ابن معصوم المدني، ط مطبعة النعمان،

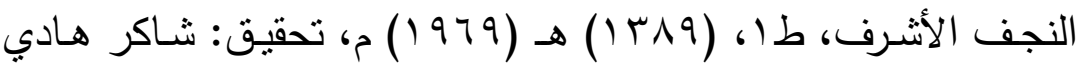

شكر

- الإيضــاح لتلخـبص المفتــاح، الخطيـب القزوينـي، ط مكتبـة الآداب، القاهرة، (1999 (199) م.

- - بديع القرآن صـ اس آ، ط نهضة مصر ، تحقيق: حفني شرف. - - البديع في نقد الثعر ، أسامة بن منقذ، ط الإدارة العامة للثقافة، القاهرة،

$$
\text { تحقيق: أحمد بدوي. }
$$

- البرهان في علوم القرآن، الزركثي، ط مكتبة التراث، القاهرة، (TVY)

$$
\text { هـ، تحقيق: محمد أبي الفضل إبراهيم. }
$$

- بغيـة الإيضـاح، عبـد المتعـال الصــيدي، ط مكتبـة الآداب، القـاهرة،

- تحربـر التحبيـر، عبـد العظبم بـن أبـي الإصـبع المصسري، ط المجلس

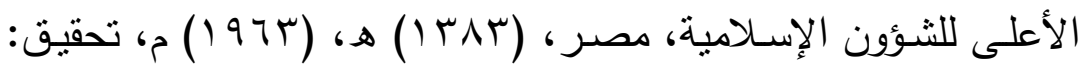

$$
\text { حفني محمد شرف. }
$$

- التشبيه المقلوب بين القبول والرد، دراسـة بلاغيـة في تراث أهل العلم،

محمد أبو العـلا الحمزاوي، بحثث منشـور بمجلة كلبـة اللغـة العربيـة -

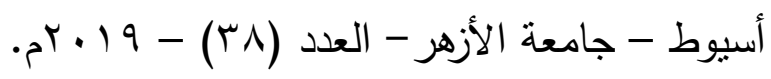

- التوقيف على مهمات التعاريف، عبد الرؤوف المناوي، ط عالم الكتب، القـاهرة، طا، (7 (1 1) هـ ( • 1999) م، تحقيـق: عبـد الحمبـد صـالح 
حوليتّ كليت اللغت العربيت بإيتاى البارود (العدد الثاني والثلاثون ـ المجلد الثالث)

- التوهم في آثار الدارسـين عرض ونقد، محمد سـعبد الغامـي، بحـث

منشور بمركز البحوث والنشر العلمي، جامعة الملك عبد العزيز • - - جـوهر الكنز ، نجـم الـدين بـن الأثبر ، ط دار المعـارف، الإسـكندرية، (9. . . (Y)، تحقيق: محمد زغلول سلام. - حدائق السحر في دقائق الثعر ، رشيد الدين الوطواط، ط المركز القومي للترجمة، القاهرة، طب، (9 ب ) م، تحقيق الدكتور / إبراهيم الثواربي. - حسـن التوسـل إلـى صـناعة الترسـل، محمـود بـن سـليمان الحلبـي، ط المطبعة الوهبية، القاهرة، (N اب I) هـ. - خزانة الأدب وغايـة الأرب، ابن حجة الحموي، ط دار الهلال، بيروت،

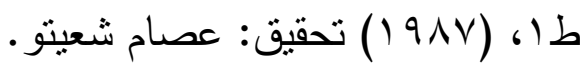
- خصائص التراكيب، محمد أبو موسىى، ط مكتبة وهبـة، طع، (7 (1 ) هـ (1997)

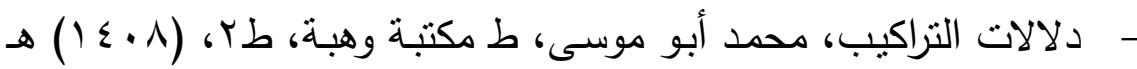
• (19人V) - دلائل الإعجـاز ، عبد القـاهر الجرجـاني، ط مكتبـة الخـانجي، القـاهرة،

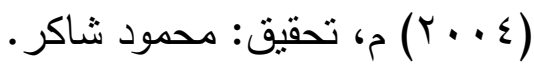
- شـرح دلائـل الإعجـاز ، محمـد إبـراهيم شـادي، ط دار اليقين للنشـر

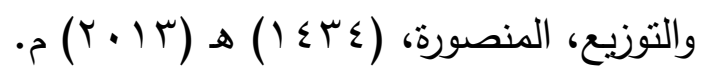
- الصساحبي في فقه اللغة، أحمد بن فارس، ط مكتبة المعارف، بيروت،

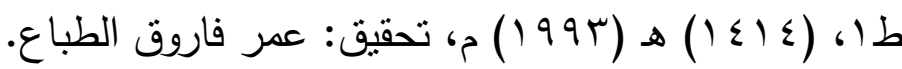
- الصـنيع البـديع في شـرح الحليـة ذات البـديع، ابـن زاكـور الفاسـي، ط مطبعة النجاح الجديدة، الدار البيضاء، طا، (r . . r) م. - الطـراز المتضـمن لأسـرار البلاغيـة وعلوم حقائق الإعجـاز ، يحيى بـن

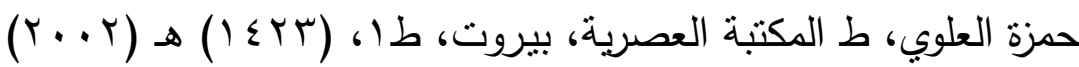
م، تحقيق: عبد الحميد هنداوي. 
حوليتّكليت اللغت العربيت بايتتاى البارود (العدد الثاني والثلاثون ـ المجلد الثالث)

- علم البيـان، بسـيوني عبـد الفتـاح فيـود، ط مؤسسـة المختـار للنشـر

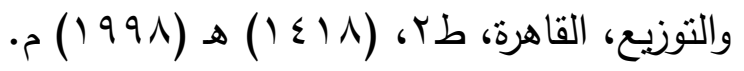

- علم المعـاني، بسيوني عبد الفتاح فيود، ط مؤسسـة المختار، القاهرة، طا - - العددة في محاسن الثـعر وآدابـه ونقده، ابن رشيق القيرواني، ط دار

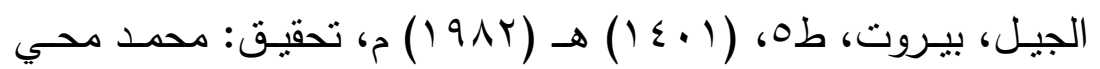

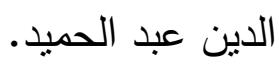
- الفروق في اللغة، أبو هلال العسكري، ط مؤسسة الرسالة، بيروت، طا ا، ( )

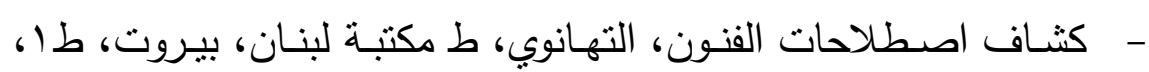

$$
\text { (997 ( ) ) م، تحقيق: علي دحروج. }
$$

- كثف اللثام عن وجه التورية والاستخدام، ابن حجة الحموي، ط المطبعة

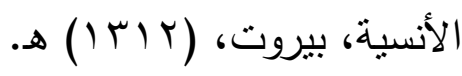
- الكلبات، أبو البقاء الكفوي، ط مؤسسة الرسالة، بيروت، طن، (9 ( ) 1)، 991 99 (م، تحقيق: عدنان دروبش. - لسـان العـرب، جمـال الـدين ابـن منظـور، ط دار المعـارف، القـاهرة، تحقيق: محمد علي الكبير وآخرين. - المزهر في علوم اللغة وأنواعها، جلال الدين السيوطي، ط دار التراث، القاهرة، طب، تحقيق: محمد أحمد جاد المولى. - معاهد التصيص على شواهد التلخيص، عبد الرحيم العباسي، ط عالم الكتب، بيـروت، (VV I I I ) هـ ( I ) م، تحقيـق: محمد محي الدين عبد الحميد، وط المطبعة البهية، القاهرة (T ابا ) هـ. - معجم المصطلحات البلاغية، أحمد مطلوب، ط مطبعة المجمع العلمي

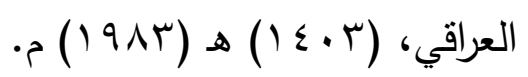


حوليتة كليت اللغت العربيت باييتاى البارود (العدد الثاني والثلاثون ـ المجلد الثالث)

- مغنـي اللبيب عن كتب الأعاريب، ابـن هثـام، ط دار الفكر، دمثـق،

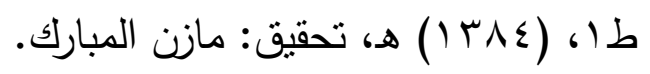

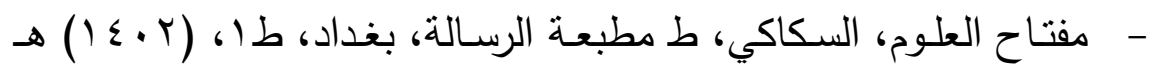
( ( 9 ) r) - مـن بلاغـة النظم العربـي، عبد العزبـز عبد المعطي عرفـة، ط عـالم

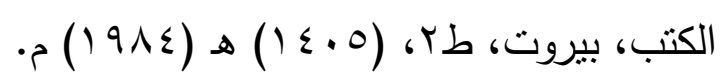
- مواهـب الفتـاح شـرح تلخهص المفتـاح، ضــن شـروح التلخيص، ابـن يعقوب المغربي، ط دار الكتب العلمية، بيروت. - - نهايـة الأرب في فنـون الأدب، شـهاب الـدين أحمـد بـن عبـد الوهـاب

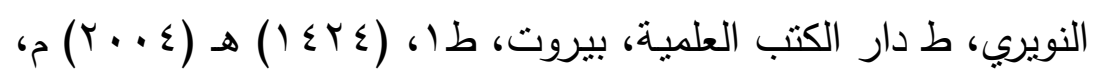
بتحقيق الدكتور / مفيد قميحة. - - نهايـة الإيجـاز في درايـة الإعجـاز ، فخرالدين الـرازي، ط دار صـادر،

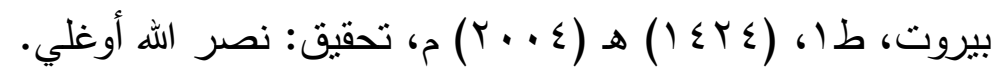


التوسم في الدرس البلاغي "فنونه وخصائصه"

حوليت كليت اللغت العربيت بإيتاى البارود (العدد الثاني والثلاثون ـ المجلد الثالث)

فهرب المواضيع

\begin{tabular}{|c|c|}
\hline رقه الصفحت & 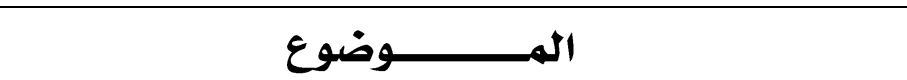 \\
\hline r990 & مقدمة \\
\hline rqqV & تمهيد - مفهوم التوهم وتطوره- أول من أثنار إليه - التوهم \\
\hline$r . r$ & المبحث الأول: التوهم في أساليب ومسائل المعاني. \\
\hline$r \cdot 1 \leq$ & المبحث الثاني: التوهم في صور البيان. \\
\hline$r \cdot r r$ & المبحث الثالث: التوهم في أساليب وفنون البديع. \\
\hline 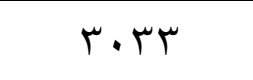 & 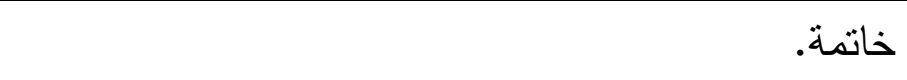 \\
\hline (1) & ثبت المصادر والمراجع. \\
\hline 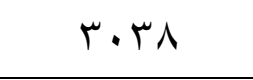 & 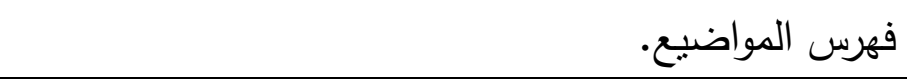 \\
\hline
\end{tabular}

